Article

\title{
Archean Rocks of the Diorite Window Block in the Southern Framing of the Monchegorsk (2.5 Ga) Layered Mafic-Ultramafic Complex (Kola Peninsula, Russia)
}

\author{
Pavel Pripachkin *, Tatiana Rundkvist, Nikolay Groshev $[$, Aiya Bazai and Pavel Serov(D) \\ Geological Institute-subdivision of the Federal Research Centre, Kola Science Centre of the Russian Academy \\ of Sciences, Fersman St. 14, Apatity 184209, Russia; rund@geoksc.apatity.ru (T.R.); \\ nikolaygroshev@gmail.com (N.G.); bazai@geoksc.apatity.ru (A.B.); serov@geoksc.apatity.ru (P.S.) \\ * Correspondence: pripaul@rambler.ru
}

Received: 24 July 2020; Accepted: 24 September 2020; Published: 25 September 2020

check for updates

\begin{abstract}
The intermediate rocks classified as diorite-gneisses occur within the southern part of the Monchegorsk (2.5 Ga) layered mafic-ultramafic complex (Kola Peninsula, Russia). These diorite-gneisses belong to a block historically known as the diorite window (DW) block. The same rocks occur in a framing of the Monchegorsk complex. The DW block is predominantly composed of diorite-gneisses and, to a lesser degree, of amphibolites. Multi-ordinal banding, complex folding, boudinage and metamorphic transformations, garnet porphyroblasts, and tourmaline veinlets are typical of the diorite-gneisses. In accordance with the U-Pb isotope data, the age of the diorite-gneisses in the DW block is $2736.0 \pm 4.6 \mathrm{Ma}$. The Sm-Nd mineral (garnet, biotite, and tourmaline) isochron for the DW rocks has yielded an age of $1806 \pm 23 \mathrm{Ma}$ (related to the processes of the Svecofennian orogeny). The DW diorite-gneisses are compared with the metadiorites of the Gabbro-10 massif. The latter is a part of the Monchegorsk complex, with U-Pb crystallization age of $2498 \pm 6 \mathrm{Ma}$. On the basis of geological and isotope-geochemical data, it is shown that the DW rocks belong to the Archean basement while the Gabbro-10 metadiorites probably represent one of the late-magmatic phases of the Monchegorsk complex.
\end{abstract}

Keywords: Archean diorite-gneisses; Monchegorsk layered mafic-ultramafic complex; Kola Peninsula

\section{Introduction}

The Monchegorsk layered mafic-ultramafic complex (hereafter the Monchegorsk complex) occupies the Monchegorsk region in the central part of the Kola Peninsula (Figure 1). The Monchegorsk complex is primarily known for its complex Cu-Ni-PGE-Cr-Fe-Ti-V mineralization. It is also interesting from the viewpoint of geology and petrology for the multi-order igneous (including rhythmic) layering, availability of features confirming the multiphase nature of its emplacement, and several genetic types of ore mineralization (contact, vein, and reef). 


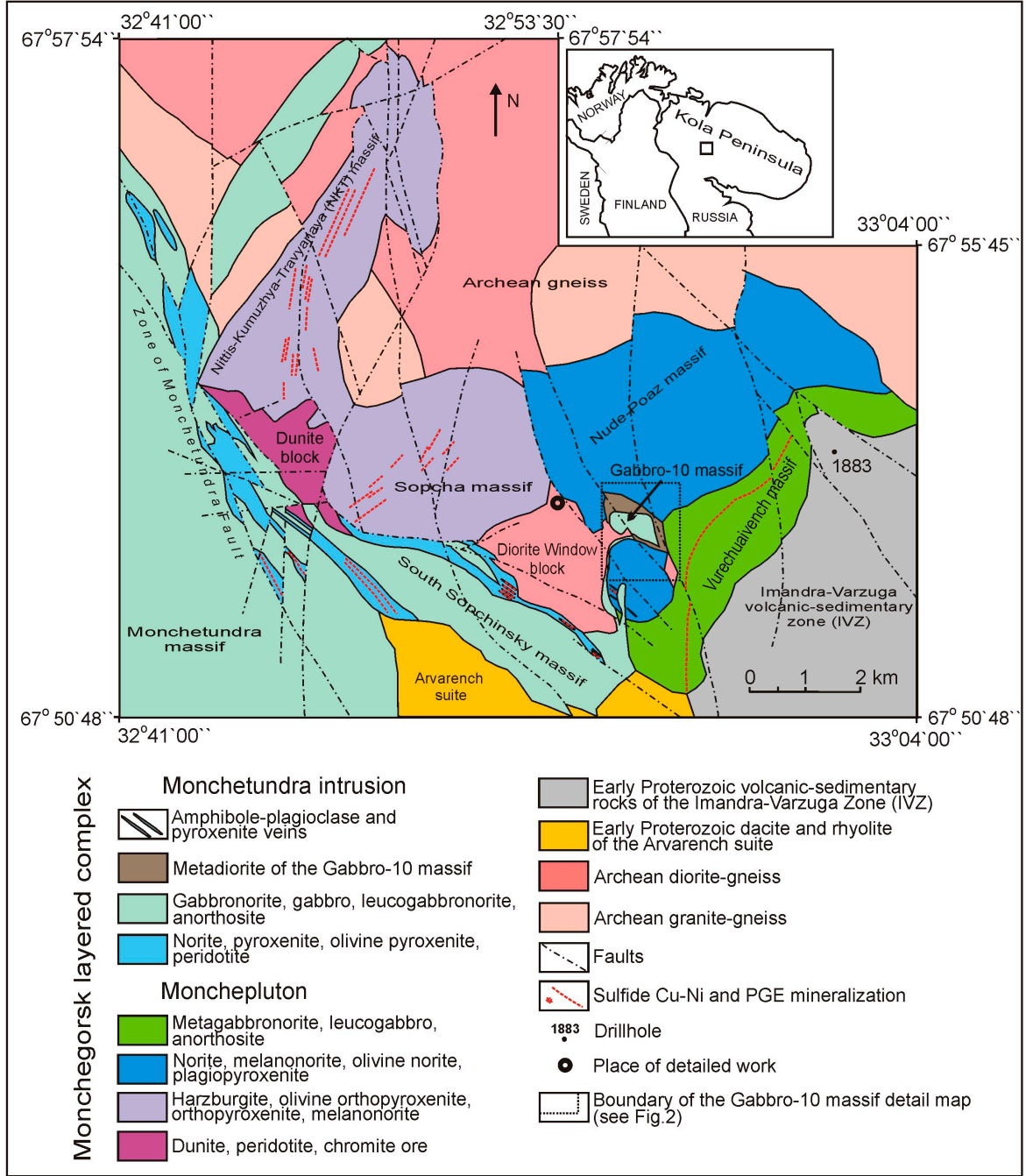

Figure 1. Geological map of the Monchegorsk complex.

However, we believe that not only rocks and ores of the Monchegorsk complex, but also rock units in the contact zone with the country rocks may be of interest for a wide geological audience. In this respect, much attention has been attracted by the southern framing of the Monchegorsk complex. Within this zone, marked by the Monchetundra fault, there are contacts of various magmatic phases of the Monchegorsk complex and areas of the implied interaction of these phases with the country diorite-gneisses, which are represented by a block of Archean rocks, the so-called diorite window (DW). Furthermore, rocks of diorite composition (metadiorites) are found in the Gabbro-10 massif, which is a part of the Monchegorsk layered complex. It is noteworthy that some researchers considered the metadiorites of the Gabbro-10 massif to be products of metasomatic alteration of the Archean basement diorites [1].

Until recently, the DW rocks were poorly studied due to the lack of practical and fundamental interest. To the contrary, the metadiorites related to the Gabbro-10 massif have been studied thoroughly to date, taking into account their essential role in the formation of various ore types in the Monchegorsk complex. In this article, we aimed to consider the compositional features of the rocks of the DW and understand which rock associations of the basement they belong to. The second question is whether the metadiorites of the Gabbro-10 massif can be genetically related to the rocks of the DW. Thus, this research provides the first data on the geology (mineralogy and geochemistry) of the DW rocks in comparison with the Gabbro-10 metadiorites. 


\section{Geological Structure of the Monchegorsk Complex}

The Monchegorsk complex includes two large intrusive units, which are the norite-orthopyroxenite-gabbronorite Monchetundra intrusion and the mafic-ultramafic Monchepluton (Figure 1). It was earlier suggested that these massifs were independent intrusions with various ages [1,2]. However, isotope-geochronological investigations have shown they have similar ages $(2497 \pm 3-2501 \pm 8 \mathrm{Ma})[3,4]$ and allowed some researchers to combine these into the single early-Proterozoic Monchegorsk complex [5,6].

The contact between the Monchetundra intrusion and Monchepluton traces the so-called Monchetundra fault. Tectonic units in the fault area are composed of rhythmically layered rocks, which were considered either as independent fissured intrusions [3] or near-fault fragments of the Monchetundra intrusion [5]. This complicated tectonic setting concentrates small massifs of mafic rocks (South Sopchinsky and Gabbro-10) whose relationships with the Monchetundra intrusion and Monchepluton remain debatable [7]. In this article, we agree with the view that the Monchetundra intrusion consists of the following parts: the Monchetundra massif itself, the South Sopchinsky massif, and the Gabbro-10 massif. Monchepluton consists of the NKT massif (Nittis, Kumuzhija, and Travianaja mountains), dunite block, Sopcha massif, and Nude-Poaz massif (Figure 1). Its eastern edge encompasses the Vurechuaivench massif whose affiliation to the Monchepluton is now deemed as reliably proven $[3,8,9]$.

The Archean DW rocks (Figure 1) occur between the Sopcha and Nude-Poaz massifs (northern contact) and South Sopchinsky and Gabbro-10 massifs (southern and eastern contacts) of the Monchegorsk complex.

The Sopcha, Nude-Poaz, and Vurechuaivench massifs form the ENE-trending branch of the Monchepluton. These massifs come into contact with the Archean basement rocks at the bottom or with blastomylonites after gabbroids as is the case with the Sopcha massif. Ascending the rock sequence the following rock alternations are observed: harzburgites; interchanging harzburgites, olivine pyroxenites, and orthopyroxenites; orthopyroxenites (Sopcha massif); plagiopyroxenites, melanonorites, and norites (Nude-Poaz massif); and metagabbronorites, leucogabbro, and anorthosites (Vurechuaivench massif). This regular rock alternation in the total sequence is twice disturbed by olivine-bearing rock horizons called the Ore Layer 330 of the Sopcha massif and the Critical Horizon of the Nude-Poaz massif. This is ascribed by many authors to additional later melt injections of corresponding composition [3]. Non-commercial sulfide $\mathrm{Cu}-\mathrm{Ni}$ and PGE mineralization is associated with the rocks of the Ore Layer 330 and Critical Horizon. The anorthosites of the Vurechuaivench massif contain a reef-type PGE deposit entered into the State Reserve Register [10,11].

The South Sopchinsky and Gabbro-10 massifs are composed of the following rock varieties: peridotites and olivine pyroxenites, norites, and leucocratic gabbronorites (South Sopchinsky massif) and the Gabbro-10 massif mainly consists of leucocratic gabbronorites (gabbro), which are overlain by the so-called metadiorites. The border between the underlying pyroxenites, norites, and leucocratic gabbronorites of the South Sopchinsky massif is accompanied by eruptive breccia and various (mainly with plagioclase-pyroxene composition) veins with sulfide-oxide and PGE mineralization [8]. At the border of the leucocratic gabbronorites and metadiorites of the Gabbro-10 massif, there is a layer of solid magnetite with iron-titanium-vanadium mineralization.

The South Sopchinsky and Vurechuaivench massifs are overlain by the Lower-Proterozoic volcano-sedimentary rocks of the Imandra-Varzuga belt and Arvarench Suite in the southern framing of the Monchegorsk layered complex.

The contacts of all massifs with the basement diorites do not crop out, being only penetrated by some deep boreholes. 


\section{Gabbro-10 Massif: Structure, Petrography, Geochemistry, and Geochronology of the Metadiorites}

The Gabbro-10 massif occurs to the south of the Nude Mountain (Figure 1) and is composed of metamorphosed mafic and intermediate igneous rocks. These rocks form a subhorizontal lens-like body with a thickness of 50-70 m, which has an elliptical shape elongated in the northwest direction with a total area of exposure of ca. $0.6 \mathrm{~km}^{2}$ (Figure 2). The mafic rocks make up the larger lower part of the lens and are represented by inequigranular-coarse-grained metagabbro forming a core on the surface. Near the lower contact of the coarse-grained metagabbro with the underlying Archean diorites, there is a zone of schistose metagabbroids.

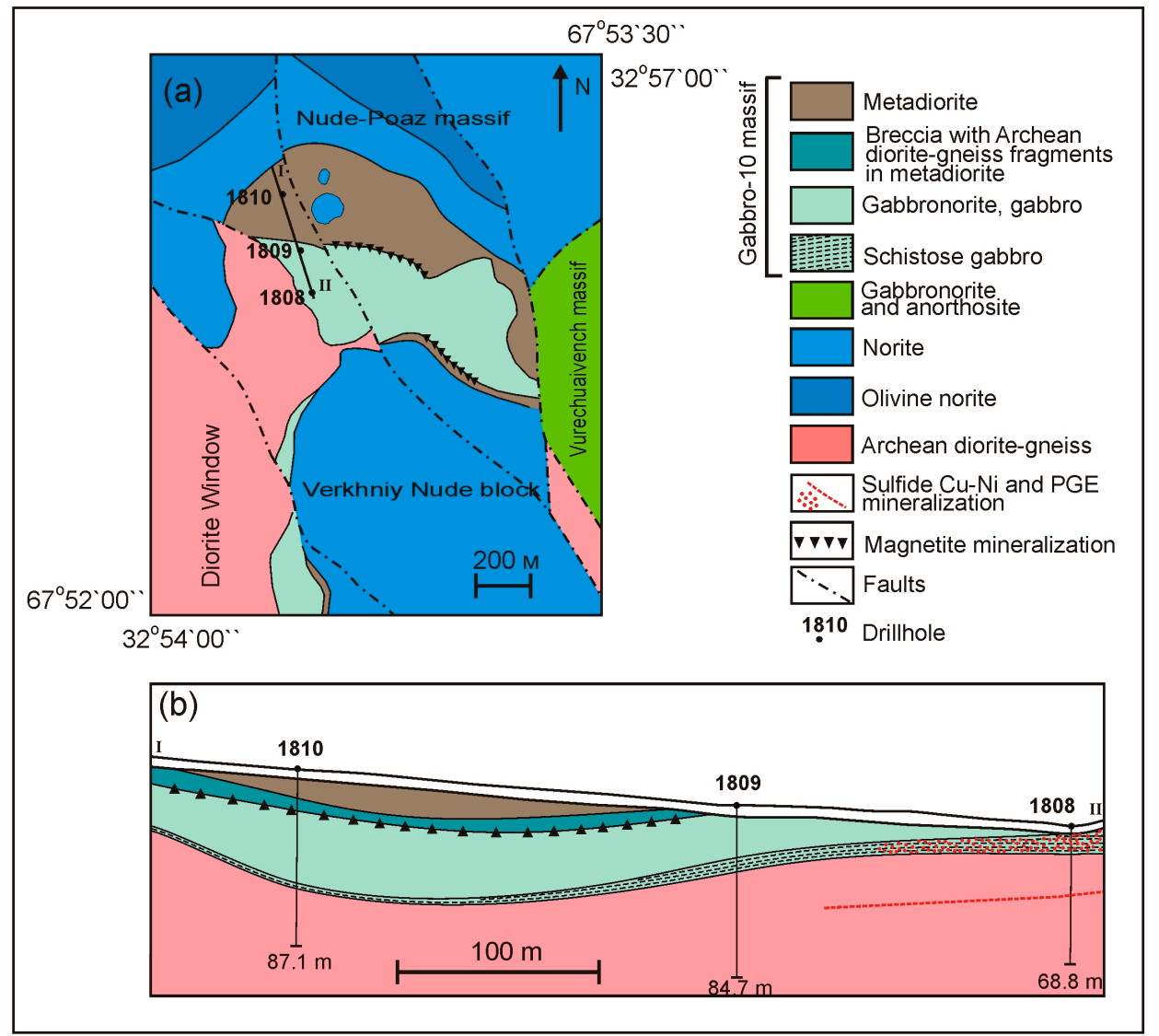

Figure 2. Geological map of the southern part of the Monchepluton (a) and the cross section along the well line 1808-1810 (b) (modified after [12]).

The core of the massif is surrounded from the flanks and partially overlain by rocks, which correspond to metadiorites in terms of mineral composition. The bottom of the sequence is marked by a zone of igneous breccia with a thickness of 5-15 $\mathrm{m}$ (Figure 2). The breccia cement is represented by metadiorites and magnetite rocks, and fragments with a size of up to $6 \mathrm{~m}$ across from Archean basement diorites with numerous veinlets of the cement material. A 1-2 m thick layer composed of magnetite of up to 90 vol.\% occurs at the bottom of the breccia zone [13].

The metadiorites macroscopically resemble Archean diorites and diorite-gneisses enclosing the Monchepluton, but differ in terms of structure and texture. The metadiorites are fine-grained massive or slightly gneissose light-grey rocks with a pink shade. The rocks are composed of albite, quartz, microcline, biotite, amphibole, chlorite, epidote, calcite, and leucoxene. The massive varieties contain grains of saussuritized plagioclase and blocks of micropegmatite. It is typical that the metadiorites constantly contain $2-5 \mathrm{vol} . \%$ of magnetite and, thus are clearly visible in the magnetic field [13].

In terms of the composition of major elements, the metadiorites containing $66-69 \%$ of $\mathrm{SiO}_{2}, 12-13 \%$ of $\mathrm{Al}_{2} \mathrm{O}_{3}, 6-7 \%$ of $\mathrm{FeO}_{\text {tot }}$. 3-4\% of $\mathrm{CaO}, 1 \%$ of $\mathrm{MgO}$, and 3-6\% of $\mathrm{Na}_{2} \mathrm{O}+\mathrm{K}_{2} \mathrm{O}$ (Table 2), sharply differ 
from metagabbro and are close to the basement rocks. At the same time, the composition of trace elements (Y, Zr, Nb, Ta, etc.) in the Gabbro-10 metadiorites and Archean basement diorite-gneisses somewhat differ [13].

The ore mineralization of the Gabbro-10 massif is represented by Fe-Ti-V oxide (related to the magnetite layer) and sulfide Cu-Ni-PGE varieties. The magnetite layer divides the rock sequence of the massif into two parts, which are the lower one represented by coarse-grained metagabbro and the upper one composed of metadiorites (Figure $2 b$ ). The ore is made up of fine- to medium-grained magnetite rocks that contain euhedral magnetite of more than 50\%, albite, quartz, amphibole, and biotite. The lower contact of the layer with the metagabbro is abrupt and oriented subhorizontally; the upper boundary is also sharp, but drawn conditionally depending on the size and shape of Archean diorite fragments. In accordance with the data of the analysis of hand specimen samples, the ore contains up to $5 \%$ of $\mathrm{TiO}_{2}$ and $0.1 \%$ of $\mathrm{V}_{2} \mathrm{O}_{5}$ [13].

The PGE-Cu-Ni mineralization of the Gabbro-10 massif is related to irregular and sometimes nested impregnation of sulfides. The impregnation is predominantly confined to the marginal zone, but often permeates into the metagabbro and diorite-gneisses of the basement (which are just developed within the DW block). The content of sulfides varies from single grains to 10 vol.\%. The sulfides are mainly represented by pentlandite, pyrrhotite, and chalcopyrite; pyrite, millerite, violarite, mackinawite, and covelline are also encountered [14].

Of the platinum group minerals, the Gabbro-10 rocks contain cotulskite, michenerite, and sperrylite with some minor PGE-bearing cobaltite [15]. The results of the borehole core and surface sampling show that the maximum Pd concentration in the schistose metagabbro of the marginal zone is $0.58 \mathrm{ppm}$, being $1.78 \mathrm{ppm}$ in the metagabbro and $2.28 \mathrm{ppm}$ in the basement diorites. The nickel content exceeds a value of $0.1 \mathrm{wt} \%$ only in single samples of schistose metagabbro and diorite-gneiss of the basement at a relatively high $\mathrm{Cu} / \mathrm{Ni}$ (ca. 2:1) ratio [12].

The results of local $\mathrm{U}-\mathrm{Pb}$ isotope age determination of the rocks of the Gabbro-10 massif are described by [13]. On the basis of morphology and internal structure of grains, the studied zircon from the metadiorites was divided by the authors into several generations.

The first zircon generation is represented by short-columnar crystals with a complex internal structure. The core of such grains has a concordant $\mathrm{U}-\mathrm{Pb}$ age of $2758 \pm 14 \mathrm{Ma}$ (concordance probability of 0.92).

The second generation does not form individual grains and occurs as growth zones, which are darker in the cathodoluminescence spectrum with relatively high uranium content. The Discordia obtained from three analyses from this generation has an upper intersection with the Concordia near an age of $2500 \mathrm{Ma}$. $\mathrm{A}^{207} \mathrm{~Pb} /{ }^{206} \mathrm{~Pb}$ subconcordant age $(\mathrm{D}=1 \%)$ corresponds to a value of $2485 \pm 3 \mathrm{Ma}$ [13].

The third generation contains large columnar grains and small anhedral segregations of polycrystal zircon often with a baddeleyite core. Seven zircon points of the third generation form a Discordia with an upper intersection corresponding to an age of $1939 \pm 16 \mathrm{Ma}$ [13].

The zircons of the first and third generation were acknowledged to be metamorphic, with the second generation zircons being igneous. However, due to poor preservation of the igneous zircon, baddeleyite age determination was carried out. A local U-Pb analysis was performed for seven baddeleyite grains from the core of the third generation zircon. The Discordia plotted on the results of this analysis has an upper intersection with the Concordia at an age of $2498 \pm 6 \mathrm{Ma}$; it was recognized by the authors as the crystallization age for the metadiorites [13].

\section{Materials and Methods}

Our research investigated the most exposed part $(200 \mathrm{~m} \times 200 \mathrm{~m})$ of the DW block near the southwestern flank of the Nude-Poaz massif. During fieldwork, a detailed mapping at the 1:10 and 1:20 scales was executed, and samples were collected for the description of the lithology (polished sections and thin sections); petrochemical features and isotope-geochemical features (including the results of chemical analysis for three diorite-gneiss samples from deep borehole 1883 sunk within the 
Imandra-Varzuga Zone (IVZ) and crossed Nude-Poaz and Vurechuaivench massifs, see Figure 1) were obtained from selected samples. Samples from the outcrops in the northwestern part of the Archean DW were used for the description of the diorite-gneisses (Table 1).

The study of the mineral morphology, imaging in back-scattered electrons (BSEs), and preliminary chemical analyses were executed on polished sections with the use of a scanning electron microscope, LEO-1450, with an energy dispersive X-ray analytical device (EDS) at the Laboratory of Physical Methods for studying rocks, ores, and minerals of the Geological Institute of the Kola Science Centre of the Russian Academy of Sciences (GI KSC RAS).

The analysis of major elements (complete silicate analysis) was undertaken at the Chemical Analytical Laboratory of the GI KSC RAS. The following methods were used for the determination of components: flame atomic absorption ( $\mathrm{Si}, \mathrm{Al}, \mathrm{Fe}, \mathrm{Mg}, \mathrm{Ca}$, and $\mathrm{Mn}$ ), flame emission ( $\mathrm{Na}$ and $\mathrm{K}$ ), photocolorimetric (Ti), gravimetric (loss on ignition (LOI) and $\mathrm{H}_{2} \mathrm{O}^{-}$), and volumetric $\left(\mathrm{CO}_{2}, \mathrm{FeO}\right)$ analyses.

The chemical composition of minerals was studied by an X-ray spectral method with an electron probe microanalyzer (Cameca MS-46, Paris, France) under the conditions of accelerating tension of $22 \mathrm{kV}$ and probe current of 30-40 nA. Artificial and natural compounds such as $\mathrm{Si}$, Ca (wollastonite), $\mathrm{Al}\left(\mathrm{Y}_{3} \mathrm{Al}_{5} \mathrm{O}_{12}\right), \mathrm{Na}$, $\mathrm{Ti}$ (lorenzenite), $\mathrm{Mg}$ (forsterite), $\mathrm{Fe}$ (hematite), $\mathrm{Mn}\left(\mathrm{MnCO}_{3}\right)$, and $\mathrm{K}$ (wadeite) were used as reference samples.

Zircons for the $\mathrm{U}-\mathrm{Pb}$ isotope studies and rock-forming minerals (garnet, tourmaline, and biotite) for the Sm-Nd isotope studies were separated at the laboratory for separation and primary sample processing of the Geological Institute of the KSC RAS in accordance with the conventional separation method using electromagnets with various intensities and heavy liquids.

The measurements of $\mathrm{Sm}$ and $\mathrm{Nd}$ concentrations and isotope Nd composition in Samples OK-7 and OK-8 were made using a seven-channel solid-source mass-spectrometer, Finnigan-MAT 262 (Waltham, MA, USA), (equipped with an Retarding Potential Quadrupole (RPQ)), in the static mode using rhenium and tantalum double filaments. Isotopic investigations were carried out according to the technique described in detail in [16]. The calculation of isochron parameters was executed using the ISOPLOT software [17]. The U-Pb age determination of zircons from the diorite-gneiss (Sample OK-15) was performed at a secondary ion microprobe, SHRIMP-II, at the Isotope Research Centre (IRS) of VSEGEI FSUE (Saint Petersburg, Russia). The U-Pb ratios were measured in accordance with a method applied at the IRC described in $[18,19]$. The intensity of the initial beam of molecular oxygen was $4 \mathrm{nA}$; the sampling crater was $20 \mu \mathrm{m} \times 25 \mu \mathrm{m}$ at a depth down to $2 \mu \mathrm{m}$. The resultant data were processed using the SQUID software [20].

The representative samples were also analyzed for rare earth and other trace elements at the Institute for Geology and Geochemistry, Uralian Branch of the RAS (Yekaterinburg) using the ICP-MS method (ICP-mass spectrometer Perkin Elmer Elan 9000). 
Table 1. Mineral composition of the studied rocks from the diorite window (DW) block and borehole 1883.

\begin{tabular}{|c|c|c|}
\hline Number & Rock Type & Thin Section Number and Its Modal Composition \\
\hline \multirow{5}{*}{ OK-5 } & \multirow{5}{*}{$\begin{array}{l}\text { Schistose diorite-gneiss with boudins of } \\
\text { massive diorite-gneiss fine-grained }\end{array}$} & \multirow{5}{*}{ 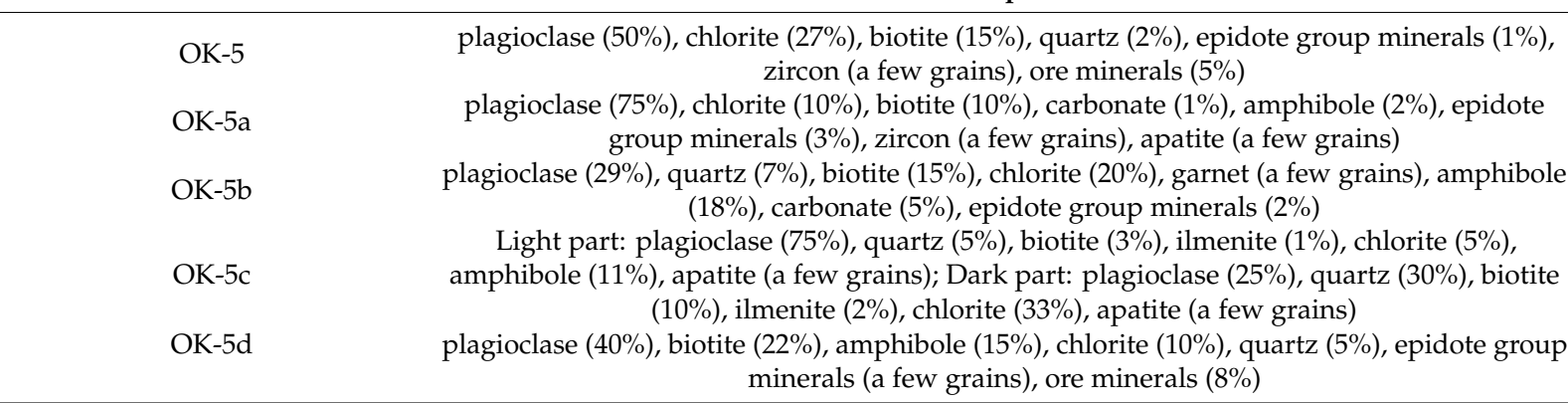 } \\
\hline & & \\
\hline & & \\
\hline & & \\
\hline & & \\
\hline & Schistose diorite-gneiss fine-grained, & $\begin{array}{c}\text { plagioclase }(45 \%) \text {, quartz }(10 \%) \text {, amphibole }(15 \%) \text {, biotite }(20 \%) \text {, epidote group minerals }(3 \%) \text {, } \\
\text { ore minerals }(7 \%) \text {, allanite (a few grains) }\end{array}$ \\
\hline OK-6 & $\begin{array}{l}\text { With boudin of amphibolites saturated } \\
\text { with magnetite, garnet, and biotite }\end{array}$ & $\begin{array}{c}\text { amphibole ( } 40 \%) \text {, quartz }(20 \%) \text {, garnet }(20 \%) \text {, plagioclase ( } 5 \%) \text {, biotite (a few grains), epidote } \\
\text { group minerals }(2 \%) \text {, ore minerals }(13 \%) \text {, apatite (a few grains) }\end{array}$ \\
\hline \multirow[b]{2}{*}{ OK-7 } & \multirow{2}{*}{$\begin{array}{l}\text { Diorite-gneiss with garnet nests, } \\
\text { inequigranular }\end{array}$} & $\begin{array}{c}\text { plagioclase }(40 \%) \text {, biotite }(38 \%) \text {, chlorite }(10 \%) \text {, quartz }(2 \%) \text {, epidote group minerals }(3 \%) \text {, ore } \\
\text { minerals }(7 \%)\end{array}$ \\
\hline & & $\begin{array}{c}\text { plagioclase (23\%), biotite }(15 \%) \text {, chlorite }(18 \%) \text {, garnet }(30 \%) \text {, amphibole }(10 \%) \text {, titanite (a few } \\
\text { grains), ore minerals }(4 \%)\end{array}$ \\
\hline OK-8 & $\begin{array}{l}\text { Diorite-gneiss with tourmaline nests, } \\
\text { inequigranular }\end{array}$ & $\begin{array}{l}\text { plagioclase }(30 \%) \text {, biotite }(15 \%) \text {, chlorite }(13 \%) \text {, quartz }(25 \%) \text {, garnet }(5 \%) \text {, amphibole }(8 \%) \text {, } \\
\text { epidote group minerals (a few grains), ore minerals }(4 \%) \text {, zircon (a few grains) } \\
\text { tourmaline }(37 \%) \text {, plagioclase }(25 \%) \text {, biotite }(8 \%) \text {, chlorite }(20 \%) \text {, quartz }(5 \%) \text {, ore minerals } \\
(5 \%) \text {, zircon (a few grains) }\end{array}$ \\
\hline OK-9 & Diorite-gneiss fine-grained & $\begin{array}{c}\text { plagioclase }(30 \%) \text {, quartz }(25 \%) \text {, biotite }(7 \%) \text {, chlorite }(13 \%) \text {, amphibole }(20 \%) \text {, garnet }(5 \%) \text {, zircon (a few grains), ore minerals (a } \\
\text { few grains) }\end{array}$ \\
\hline OK-10 & $\begin{array}{l}\text { The material of a granite vein crossing } \\
\text { diorite-gneiss }\end{array}$ & quartz $(80 \%)$, feldspar $(12 \%)$, chlorite $(8 \%)$, allanite (a few grains), ore minerals $(1 \%)$ \\
\hline OK-15 & Diorite-gneiss fine-grained & $\begin{array}{l}\text { plagioclase }(35 \%) \text {, quartz }(15 \%) \text {, biotite }(18 \%) \text {, amphibole }(15 \%) \text {, chlorite }(10 \%) \text {, epidote group minerals }(2 \%) \text {, ore minerals }(5 \%) \text {, } \\
\text { zircon (a few grains) }\end{array}$ \\
\hline $1883 / 631.2$ & Biotite gneiss fine-grained & plagioclase $(55 \%)$, quartz $(25 \%)$, biotite $(15 \%)$, amphibole $(5 \%)$, chlorite $(10 \%)$ \\
\hline $1883 / 653.1$ & Biotite gneiss fine-grained & plagioclase $(35 \%)$, quartz $(15 \%)$, biotite $(25 \%)$, amphibole $(15 \%)$, ore minerals $(2 \%)$, titanite $(8 \%)$, apatite (a few grains) \\
\hline 1883/733.6 & Biotite gneiss fine-grained & plagioclase $(45 \%)$, quartz $(15 \%)$, biotite $(25 \%)$, amphibole $(15 \%)$, chlorite $(10 \%)$, epidote group minerals $(4 \%)$, ore minerals $(1 \%)$ \\
\hline
\end{tabular}




\section{Results}

\subsection{Geological Features of the DW Block}

The fieldworks and further data processing were executed in 2017-2018 within the small and perfectly exposed site of the DW block at the south-eastern foot of Nude Mountain (Figure 1).

In accordance with the obtained data, the study area was predominantly composed of diorite-gneisses and, to a lesser degree, of amphibolites. The multi-order banding, complex folding, boudinage (Figure 3), and metamorphic transformations are typical of the diorite-gneisses.

The macro-banding was expressed by the alternation of massive and strongly schistose diorite-gneiss layers (with a thickness of a few meters; Figure 3a). The strike of banding was nearly west $\left(280^{\circ}\right)$; the rock contacts dipped at an angle of $60-65^{\circ}$ to the southwest. In turn, the banded texture or micro-banding of diorite-gneisses was caused by the alternation of leucocratic layers, where quartz and feldspar dominated with more melanocratic ones, where biotite and amphibole prevailed (Figures $3 \mathrm{~b}$ and 4). Elongated schlieren of large garnet porphyroblasts with various shapes and sizes (up to $2-3 \mathrm{~cm}$ across) were clearly visible on the weathered surface of schistose diorite-gneisses (Figure 3c, Figure 5, and Figure 6), in addition to aggregates (nests and schlieren) of black tourmaline (Figure 6).
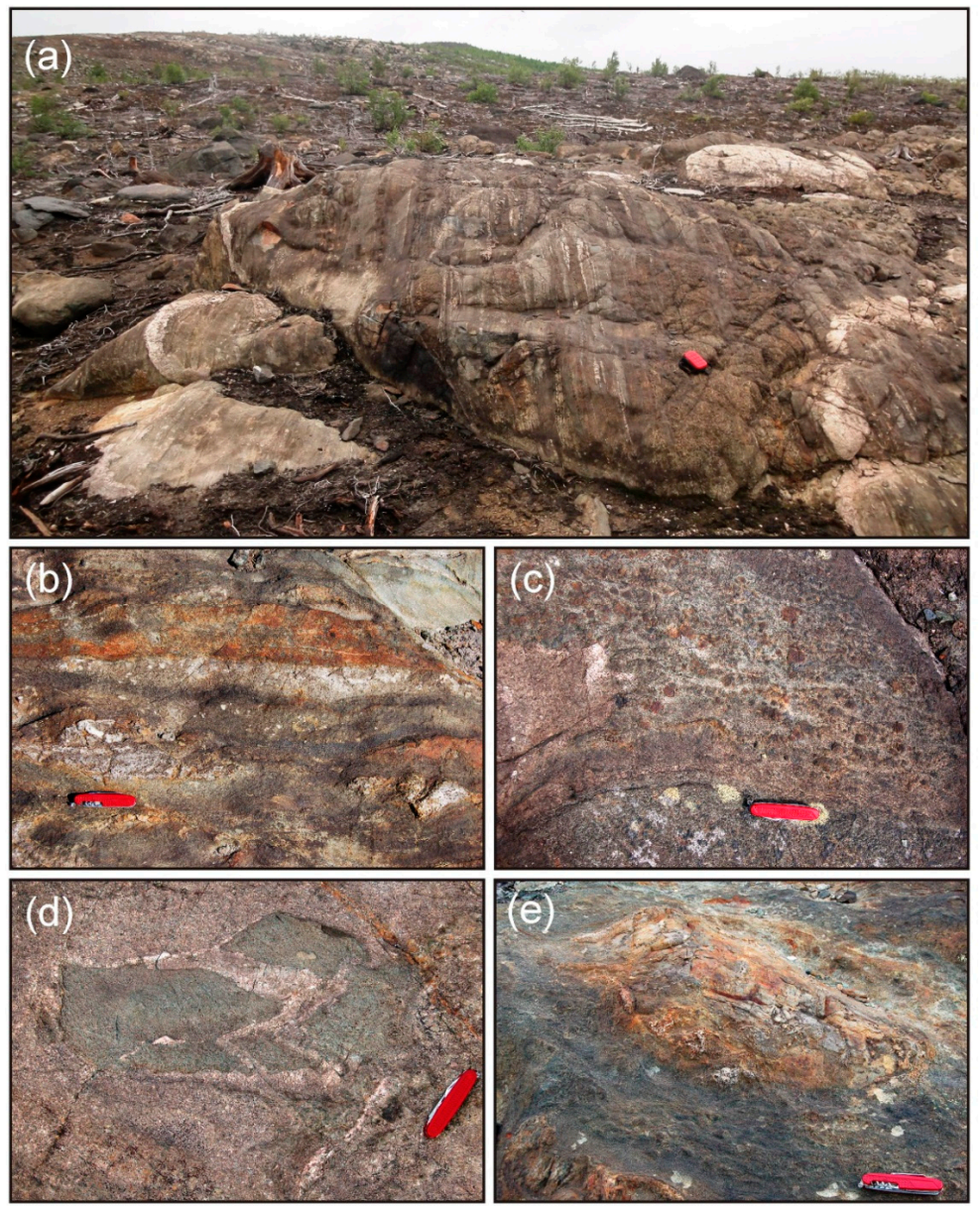

Figure 3. Geological outcrops within the DW block: banded diorite-gneiss (a); alternation of amphibolite and diorite-gneiss (b), garnet porphyroblasts in diorite-gneiss (c), torn boudins of amphibolite in diorite-gneiss (d), and boudin of garnet amphibolite with oxide mineralization (e). 

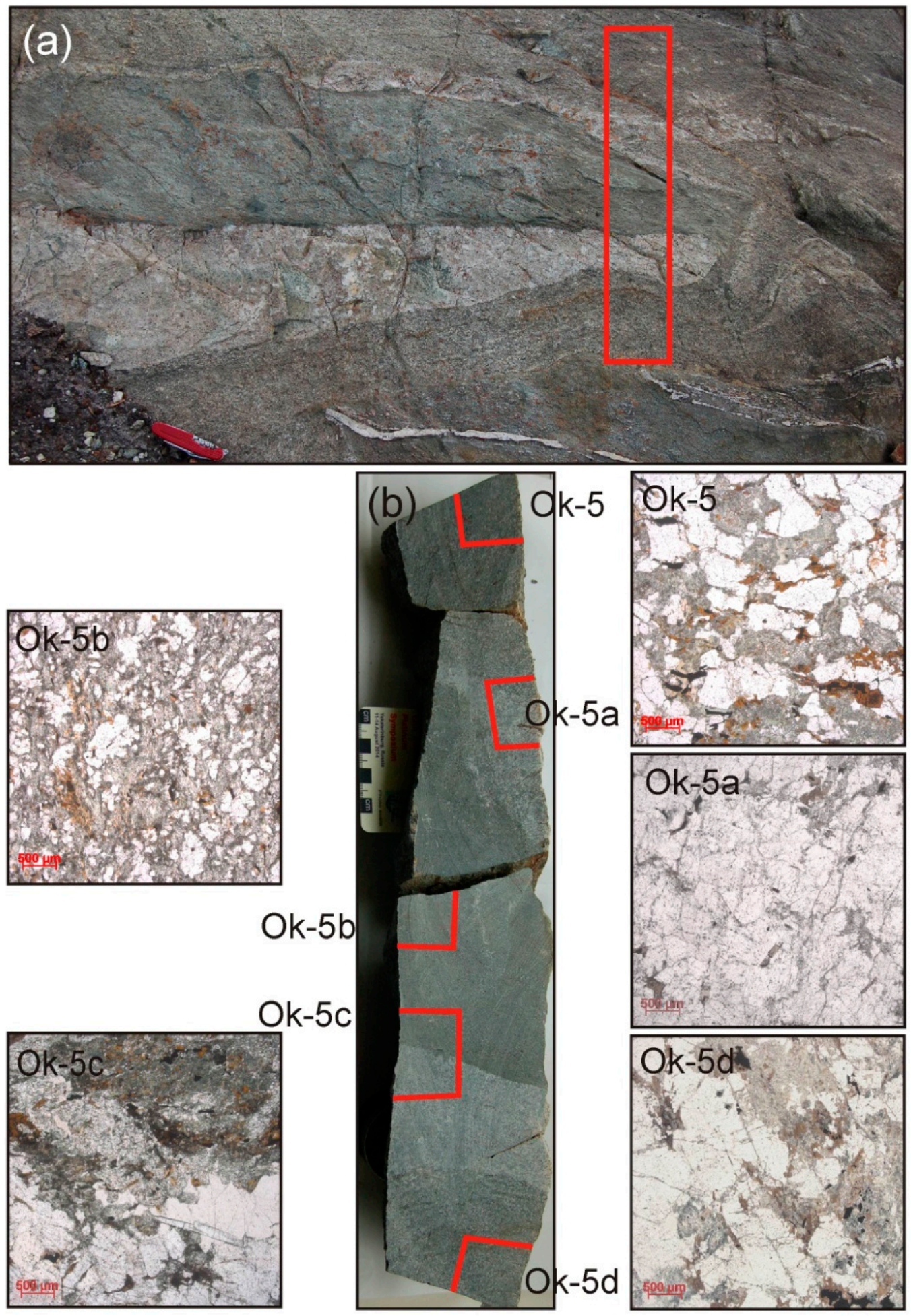

Figure 4. Boudins and leucocratic gneiss lenses among melanocratic rocks. (a) Outcrop, the red rectangle shows the contour where the sample shown in (b) was cut. The red lines in (b) show the sections of the sample from which transparent thin sections were made. Corresponding photos in plane polarized light are shown on fragments OK-5-OK-5d. 

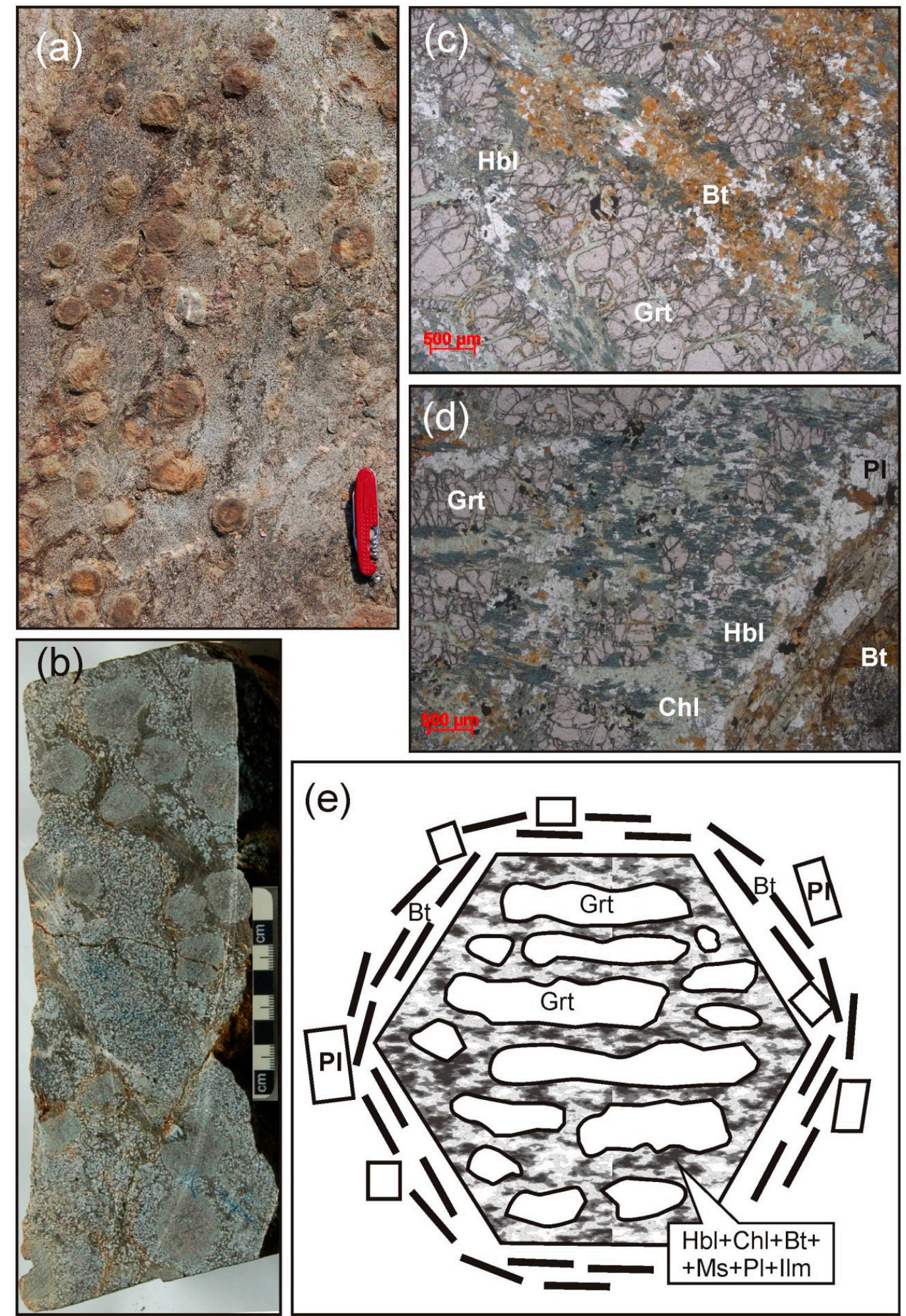

Figure 5. Garnet porphyroblasts in diorite-gneiss: view in the outcrop (a), view in a polished slice of rock $(\mathbf{b})$, photo of a thin section in plane polarized light $(\mathbf{c}, \mathbf{d})$, and internal structure $(\mathbf{e})$. Bt-biotite, $\mathrm{Pl}$ —plagioclase, Grt—garnet, $\mathrm{Hbl}$ —hornblende, Chl—chlorite, Ms—muscovite, Ilm—ilmenite. 

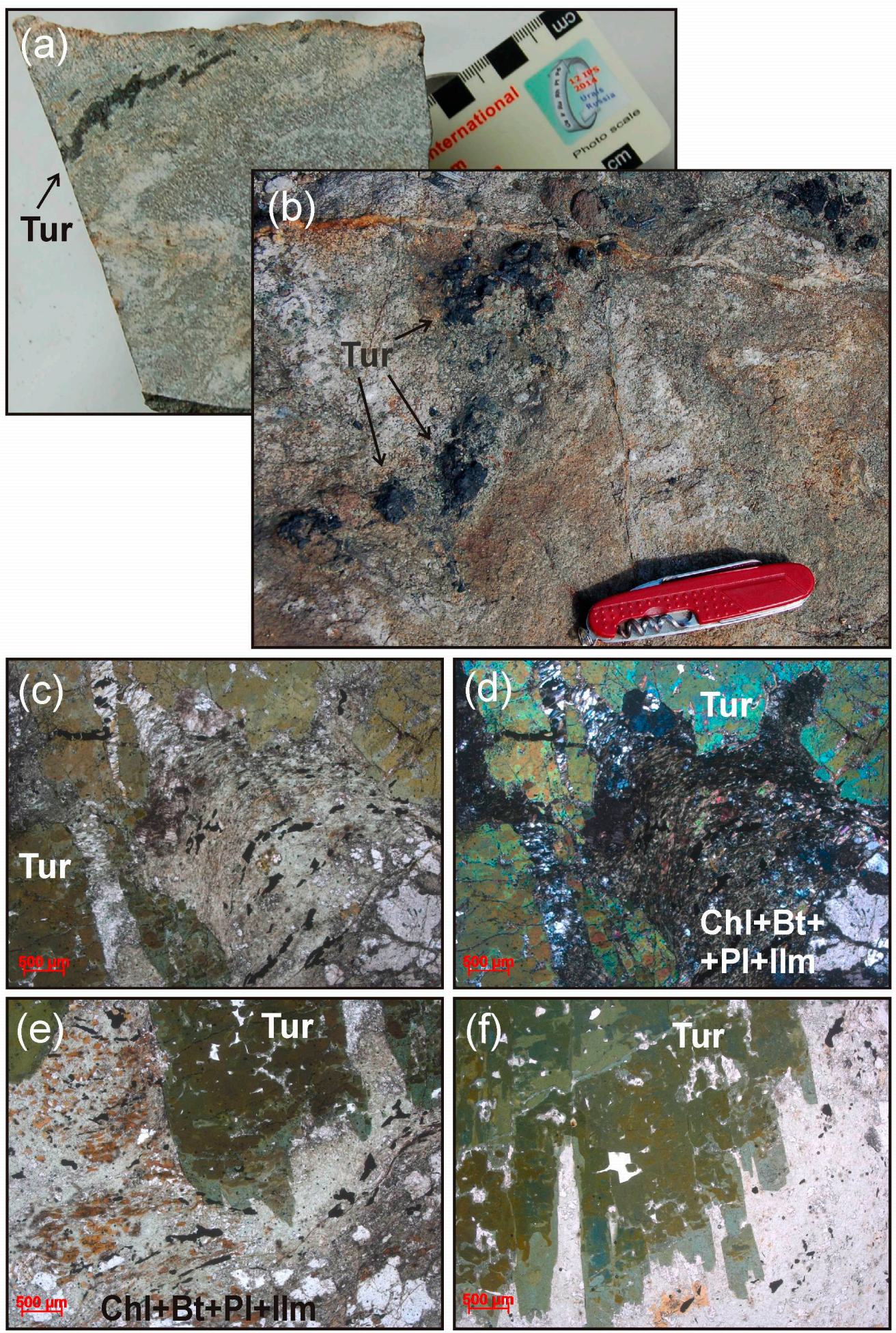

Figure 6. Tourmaline grains in diorite-gneiss: view in a piece of rock (a), view in the outcrop (b), photo of thin sections in plane polarized light $(\mathbf{c}, \mathbf{e}, \mathbf{f})$, and photo of a thin section in crossed polarizes light $(\mathbf{d})$. Tur—tourmaline, $\mathrm{Chl}$-chlorite, $\mathrm{Bt}$-biotite, $\mathrm{Pl}$-plagioclase, Ilm—ilmenite.

Within the area, boudinage structures are common. There are numerous boudins of various rock compositions (Figures 3, 4 and 7) such as metadolerites, garnet-hornblende amphibolites, and massive diorite-gneisses. The boudins have an oval (Figure 3d,e) or elongated shape (Figure $4 \mathrm{a}$ ). In some cases, 
it is obvious that the boudins were faulted and the resultant fissures were filled in with fine-grained material such as quartz, amphibole, chlorite, or their mixture (Figure 3d).
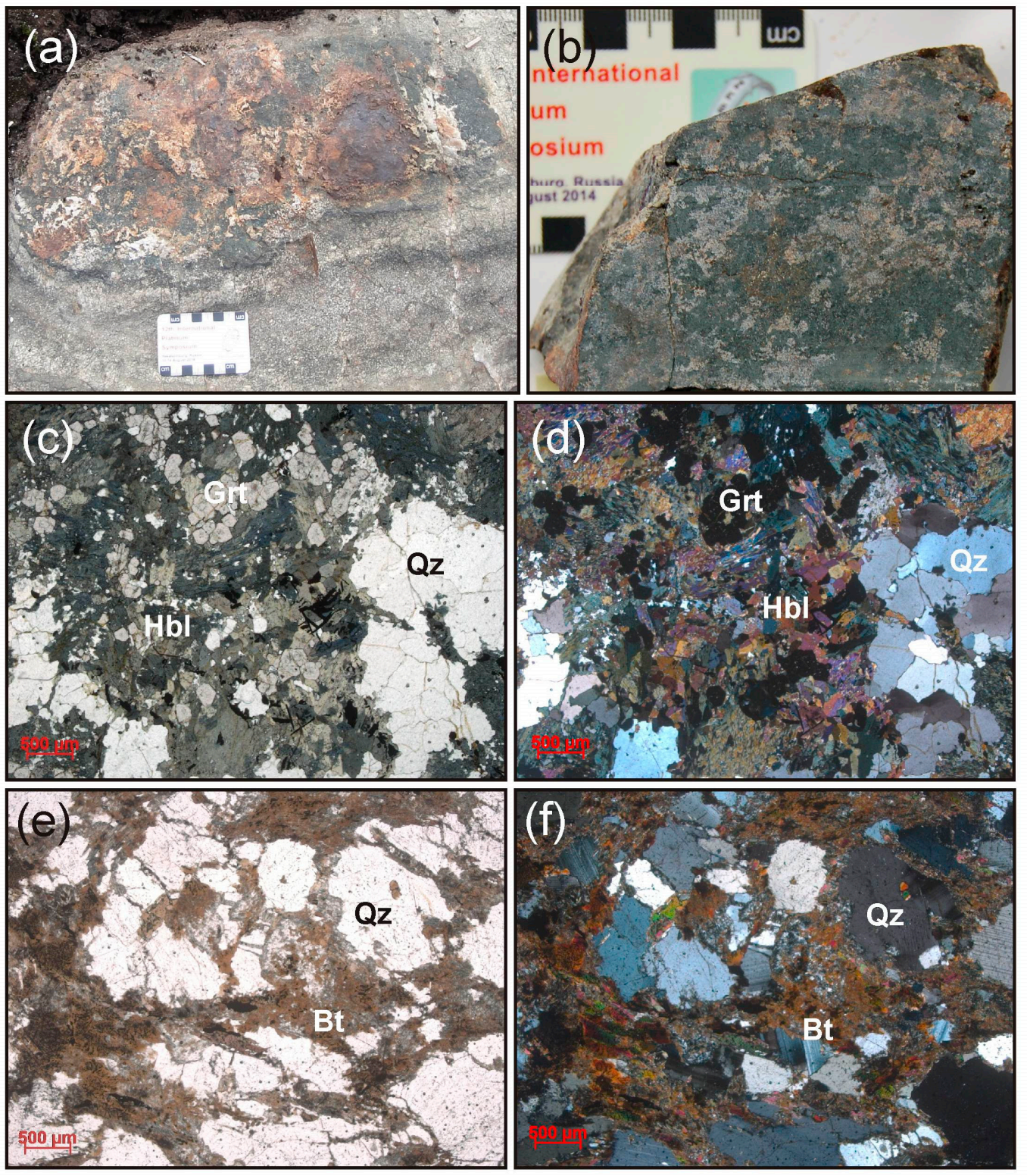

Figure 7. Boudin of garnet amphibolite with oxide mineralization: view in the outcrop (a), view in a sawn piece of rock (b), photo of transparent thin sections in plane polarized light $(\mathbf{c}, \mathbf{e})$, and photo of transparent thin sections in crossed polarized light $(\mathbf{d}, \mathbf{f})$. Grt—garnet, Hbl—hornblende, Bt—biotite, Qz-quartz.

All of the rocks of the area are penetrated by plagioclase-quartz veins (Figure 3a) with northern, western, and north-western strikes. The thickness of the veins varies from 1 to $12 \mathrm{~cm}$ for an extension of over $5 \mathrm{~m}$. Furthermore, metadolerite dikes (with a prevailing northern strike) with a thickness of several centimeters to a few meters were encountered. 


\subsection{Petrography}

The biotite and amphibole-biotite gneisses were the most common within the studied site (Figure 4a). The leucocratic varieties of amphibole-biotite gneisses in a light-grey hand specimen consisted of plagioclase for $75 \%$ and included quartz, biotite, actinolite, chlorite, and ilmenite (Figure 4, $\mathrm{OK} 5 \mathrm{a})$. The melanocratic varieties of amphibole-biotite gneisses in a dark-grey or greenish-grey hand specimen contained a maximum of $50 \%$ of plagioclase; minor minerals were biotite, actinolite, quartz, chlorite with a few grains of ilmenite, (Ce-) allanite, zircon, and apatite (Figure 4, OK-5, OK-5b). The gneisses were mylonitized and the rock was locally transformed into a microclastic (locally ultramylonitized) mass.

Plagioclase in the leucocratic varieties occurred as regular short-columnar (prismatic) grains or fragments and corresponded to andesine (An 30-47, optical analysis) in composition. It is sericitized and saussuritized. The gneisses contained extensive bands composed of large garnet porphyroblasts. The length of these bands was a few dozens of meters and the width was a maximum of $50 \mathrm{~cm}$; the strike coincided with the common schistosity and banding of the rocks (Figure 5).

Evidently garnet crystals with a size of ca. $2 \mathrm{~cm}$ were clearly visible in the outcrops. However, it was seen under the microscope that garnet porphyroblasts had a heterogeneous internal structure. Garnet was only contained in a relic form, i.e., in the form of vermicular aggregates with a size varying from a few millimeters to $1.5 \mathrm{~cm}$ (Figure 5e). Elongated relic garnet segregations and grains of other minerals in porphyroblasts stretched out in the direction coinciding with the strike of the garnet bands and common gneiss banding. The internal rims of the porphyroblasts consisted of fine-grained hornblende, chlorite, biotite, muscovite, and ilmenite. The porphyroblasts were surrounded by plagioclase crystals and biotite plates concordantly encircling their contours (Figure 5e).

In the gneisses, there were also aggregates of black tourmaline crystals (Figure 6). Tourmaline crystal intergrowths with a size of a maximum of $1 \mathrm{~cm}$ form bended chains with a length of up to $30 \mathrm{~cm}$. The strike of chains was concordant with the total schistosity and banding of the rocks. The intergrowths consisted of numerous prismatic tourmaline grains located parallel or at low angles to each other. The tourmaline was brightly colored under the microscope with pleochroism from light-yellow in $\mathrm{Ng}$ to olive-brown in Np. Large crystals show a mottled color. The apexes of prismatic tourmaline crystals were less colored. The tourmaline crystals contained numerous inclusions of matrix minerals such as quartz and plagioclase. The matrix minerals surrounded the boundaries of tourmaline porphyroblasts in such a way that the ilmenite grains were lined up in chains, whereas the biotite plates were oriented parallel to the tourmaline grain boundaries (Figure 6).

Garnet amphibolites also occurred as lenses and boudins within the gneisses. These were visible due to their dark-brown color (Figure 3a). These rocks were locally mylonitized (especially in the marginal part of boudins) and contained rare sulfide impregnations (Figure 7 ) at a maximum of $0.5 \%$ (see details in Section 5.5 Ore mineralization).

Garnet amphibolites consisted of hornblende, quartz, garnet, plagioclase, biotite, epidote, magnetite, and ilmenite with scarce apatite and (Ce-) allanite. Garnet formed isometric grains and appeared as aggregates. The size of individual grains did not exceed $1 \mathrm{~mm}$. Some crystals were idioblastic; the majority of crystals were subidioblastic. The morphology of the garnet and tourmaline segregations in the diorite-gneisses and amphibolites of the DW rocks is shown in Figure 8. 

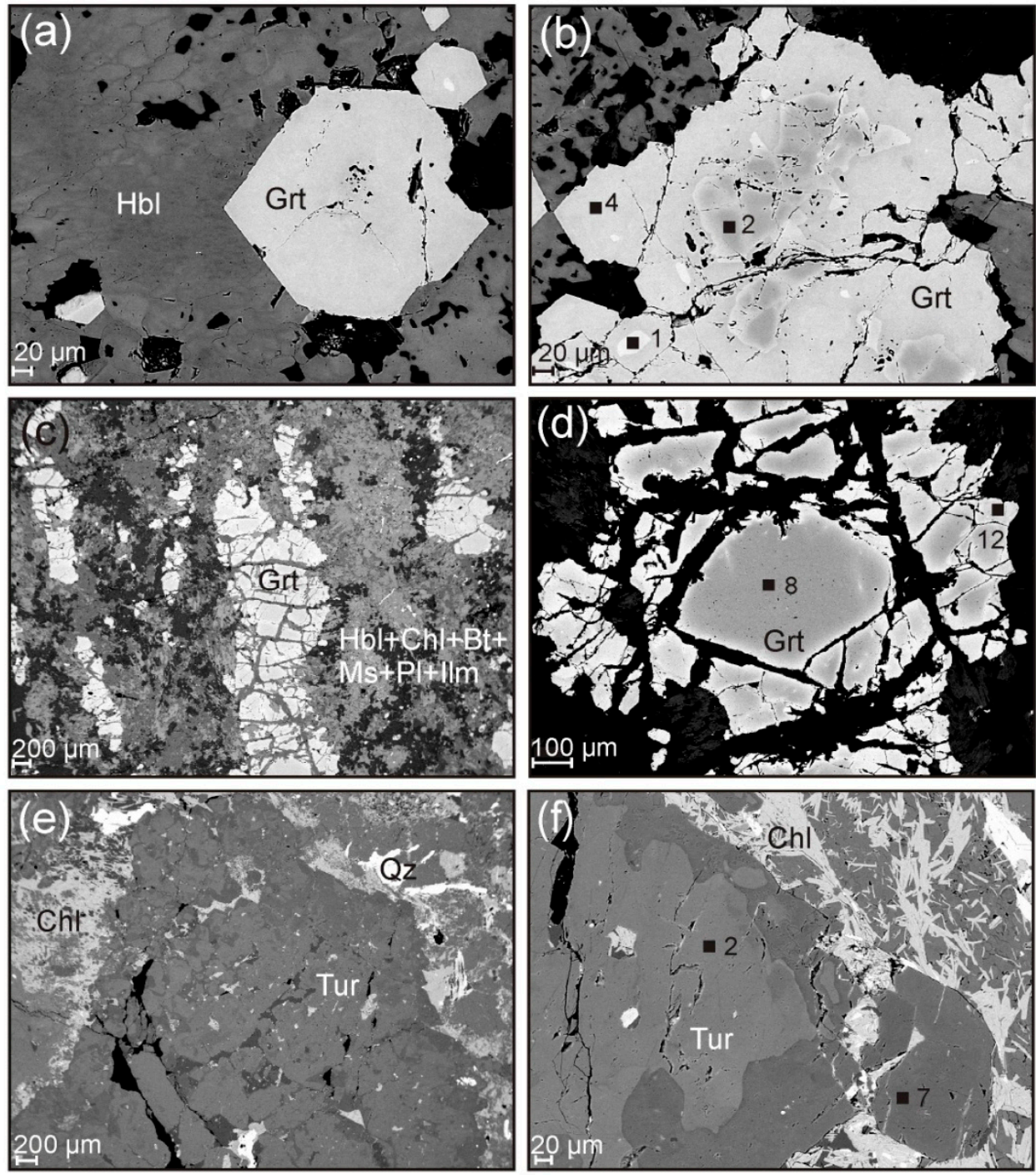

Figure 8. Garnet and tourmaline in the rocks from the DW block. (a,b) Garnet in garnet amphibolite, sample OK-6; (c,d) garnet from schlierens in diorite-gneiss, sample OK-7; (e,f) and tourmaline from schlierens in diorite-gneiss, sample OK-8. Back-scattered electron (BSE) images. Black squares indicate the points of microprobe analysis. Microprobe analysis point numbers correspond to the numbers in Table 3 (tourmaline) and Table 5 (garnet). Grt—garnet, Hbl—hornblende, Chl—chlorite, Bt—biotite, Ms-muscovite, Pl- plagioclase, Ilm-ilmenite, Qz-quartz, Tur-tourmaline.

\subsection{Chemical Composition of Tourmaline and Garnet}

Based on field observations, we assumed that schlieren tourmaline and porphyroblast garnet in gneisses were late minerals. We then wanted to confirm this hypothesis with the help of geochronological data. In addition, it was important for us to know whether the garnets from porphyroblasts in gneisses and garnets from amphibolites differ in composition. Therefore, we studied the chemical compositions of tourmaline and garnet from gneisses and amphibolites.

The tourmaline chemical composition is shown in Table 2. The tourmaline was zoned and the marginal parts of crystals were depleted in $\mathrm{Ti}$ and $\mathrm{Ca}$, and enriched in $\mathrm{Na}$. Large analytical errors did not allow calculating the crystallochemical tourmaline formulas. However a high content of both $\mathrm{Mg}$ and Fe demonstrated that tourmaline occupied an intermediate position between dravite and schorl in terms of composition. 
Table 2. Chemical composition of tourmaline from the rocks of the DW block (wt \%).

\begin{tabular}{|c|c|c|c|c|c|c|c|}
\hline \multirow[t]{2}{*}{ Element } & \multirow[t]{2}{*}{1} & 2 & 3 & 4 & 5 & 6 & 7 \\
\hline & & \multicolumn{4}{|c|}{ Hard Core } & \multicolumn{2}{|c|}{ Selvage } \\
\hline $\mathrm{SiO}_{2}$ & 37.78 & 33.374 & 33.525 & 33.159 & 32.702 & 35.812 & 35.217 \\
\hline $\mathrm{TiO}_{2}$ & 1.08 & 0.594 & 0.968 & 1.097 & 1.550 & 0.701 & 0.332 \\
\hline $\mathrm{Al}_{2} \mathrm{O}_{3}$ & 33.38 & 29.838 & 30.844 & 29.040 & 29.564 & 30.780 & 31.422 \\
\hline $\mathrm{Cr}_{2} \mathrm{O}_{3}$ & 0.06 & 0.000 & 0.000 & 0.074 & 0.091 & 0.000 & 0.115 \\
\hline $\mathrm{V}_{2} \mathrm{O}_{5}$ & 0.11 & n.d. & n.d. & n.d. & n.d. & n.d. & n.d. \\
\hline $\mathrm{FeO}_{\text {total }}$ & n.d. & 7.851 & 7.282 & 8.091 & 8.020 & 6.857 & 6.308 \\
\hline $\mathrm{Fe}_{2} \mathrm{O}_{3}$ & 7.13 & n.d. & n.d. & n.d. & n.d. & n.d. & n.d. \\
\hline $\mathrm{FeO}$ & 1.80 & n.d. & n.d. & n.d. & n.d. & n.d. & n.d. \\
\hline $\mathrm{MnO}$ & 0.012 & 0.000 & 0.000 & 0.000 & 0.000 & 0.000 & 0.000 \\
\hline $\mathrm{MgO}$ & 7.41 & 7.005 & 6.874 & 6.521 & 6.199 & 7.136 & 6.855 \\
\hline $\mathrm{CaO}$ & 2.14 & 2.466 & 2.594 & 2.178 & 2.257 & 1.060 & 0.534 \\
\hline $\mathrm{Na}_{2} \mathrm{O}$ & 0.62 & 1.005 & 1.032 & 1.281 & 1.099 & 1.627 & 1.543 \\
\hline $\mathrm{K}_{2} \mathrm{O}$ & 0.10 & 0.051 & 0.062 & 0.059 & 0.065 & 0.034 & 0.027 \\
\hline $\mathrm{H}_{2} \mathrm{O}^{-}$ & 0.28 & n.d. & n.d. & n.d. & n.d. & n.d. & n.d. \\
\hline LOI & 1.45 & n.d. & n.d. & n.d. & n.d. & n.d. & n.d. \\
\hline F & 0.21 & n.d. & n.d. & n.d. & n.d. & n.d. & n.d. \\
\hline $\mathrm{Cl}$ & 0.019 & n.d. & n.d. & n.d. & n.d. & n.d. & n.d. \\
\hline $\mathrm{Li}_{2} \mathrm{O}$ & 0.001 & n.d. & n.d. & n.d. & n.d. & n.d. & n.d. \\
\hline $\mathrm{B}_{2} \mathrm{O}_{3}$ & 5.70 & n.d. & n.d. & n.d. & n.d. & n.d. & n.d. \\
\hline Total & 99.28 & 82.184 & 83.181 & 81.500 & 81.547 & 84.007 & 82.353 \\
\hline
\end{tabular}

Note: 1 -result of a complete chemical analysis of a separate mineral; $2-7-$ microprobe analysis; LOI-loss on ignition; n.d.- not determined.

The almandine component predominated in the composition of the garnet from the porphyroblasts in the gneisses and from the amphibolites (Table 3).

Table 3. Chemical composition of garnets from the rocks of the DW block (wt \%).

\begin{tabular}{|c|c|c|c|c|c|c|c|c|c|c|c|c|c|}
\hline & 1 & 2 & 3 & 4 & 5 & 6 & 7 & 8 & 9 & 10 & 11 & 12 & 13 \\
\hline Samples & \multicolumn{5}{|c|}{ OK-6 } & \multicolumn{8}{|c|}{ OK-7 } \\
\hline & \multicolumn{3}{|c|}{ Hard Core } & \multicolumn{2}{|c|}{ Selvage } & \multicolumn{4}{|c|}{ Hard Core } & \multicolumn{4}{|c|}{ Selvage } \\
\hline $\mathrm{SiO}_{2}$ & 36.489 & 36.802 & 37.055 & 37.144 & 36.279 & 38.511 & 38.585 & 38.118 & 38.104 & 37.746 & 38.212 & 36.889 & 36.757 \\
\hline $\mathrm{Al}_{2} \mathrm{O}_{3}$ & 20.219 & 20.358 & 20.528 & 20.260 & 20.032 & 21.363 & 21.330 & 21.116 & 21.523 & 20.547 & 20.896 & 20.868 & 20.979 \\
\hline $\mathrm{Cr}_{2} \mathrm{O}_{3}$ & 0.000 & 0.000 & 0.000 & 0.000 & 0.000 & 0.063 & 0.104 & 0.084 & 0.094 & 0.104 & 0.075 & 0.066 & 0.143 \\
\hline $\mathrm{FeO}_{\text {total }}$ & 36.030 & 32.328 & 33.560 & 31.813 & 32.100 & 31.460 & 31.955 & 32.229 & 32.227 & 31.753 & 32.855 & 33.473 & 33.437 \\
\hline $\mathrm{MnO}$ & 3.272 & 1.961 & 3.164 & 3.190 & 2.970 & 0.926 & 0.765 & 2.466 & 1.119 & 6.450 & 3.339 & 4.278 & 3.760 \\
\hline $\mathrm{MgO}$ & 2.092 & 4.555 & 3.299 & 0.911 & 0.984 & 6.374 & 6.376 & 5.176 & 5.740 & 2.283 & 3.753 & 3.266 & 3.139 \\
\hline $\mathrm{CaO}$ & 1.312 & 1.743 & 1.787 & 5.973 & 6.050 & 1.492 & 1.532 & 1.135 & 1.427 & 1.458 & 1.443 & 1.174 & 1.299 \\
\hline Total & 99.414 & 97.747 & 99.393 & 99.291 & 98.415 & 100.189 & 100.647 & 7100.324 & 4100.234 & 100.341 & 1100.573 & 100.014 & 99.514 \\
\hline \multicolumn{14}{|c|}{ Formula coefficients } \\
\hline $\mathrm{Si}$ & 5.978 & 5.999 & 5.999 & 6.047 & 5.977 & 6.036 & 6.025 & 6.028 & 6.002 & 6.079 & 6.077 & 5.956 & 5.961 \\
\hline $\mathrm{Al}$ & & & & & & & & & & & & 0.030 & 0.028 \\
\hline Total Z & 5.978 & 5.999 & 5.999 & 6.047 & 5.977 & 6.036 & 6.025 & 6.028 & 6.002 & 6.079 & 6.077 & 5.986 & 5.989 \\
\hline $\mathrm{Al}$ & 3.904 & 3.912 & 3.917 & 3.888 & 3.891 & 3.946 & 3.926 & 3.936 & 3.996 & 3.900 & 3.916 & 3.942 & 3.983 \\
\hline $\mathrm{Fe}^{+3}$ & 0.110 & 0.088 & 0.084 & 0.081 & 0.125 & 0.023 & 0.050 & 0.034 & & 0.034 & 0.027 & 0.050 & \\
\hline $\mathrm{Cr}$ & & & & & & 0.007 & 0.013 & 0.011 & 0.011 & 0.013 & 0.009 & 0.008 & 0.017 \\
\hline Total Y & 4.014 & 4.000 & 4.001 & 3.969 & 4.016 & 3.976 & 3.989 & 3.981 & 4.007 & 3.947 & 3.952 & 4.000 & 4.000 \\
\hline $\mathrm{Mg}$ & 0.511 & 1.106 & 0.796 & 0.221 & 0.242 & 1.489 & 1.484 & 1.22 & 1.348 & 0.548 & 0.890 & 0.786 & 0.759 \\
\hline $\mathrm{Fe}^{+2}$ & 4.827 & 4.319 & 4.460 & 4.250 & 4.299 & 4.101 & 4.123 & 4.229 & 4.245 & 4.242 & 4.330 & 4.470 & 4.535 \\
\hline $\mathrm{Mn}$ & 0.454 & 0.270 & 0.434 & 0.440 & 0.415 & 0.123 & 0.101 & 0.331 & 0.149 & 0.880 & 0.450 & 0.585 & 0.516 \\
\hline $\mathrm{Ca}$ & 0.230 & 0.305 & 0.310 & 1.042 & 1.068 & 0.250 & 0.256 & 0.192 & 0.240 & 0.252 & 0.246 & 0.203 & 0.226 \\
\hline Total X & 6.022 & 6.000 & 6.000 & 5.953 & 6.024 & 5.963 & 5.964 & 5.972 & 5.982 & 5.922 & 5.916 & 6.044 & 6.036 \\
\hline \multicolumn{14}{|c|}{ Molecular percentages of the final members of the garnet group } \\
\hline almandine & 80.2 & 72.0 & 74.3 & 71.4 & 71.4 & 68.8 & 69.1 & 70.8 & 71.0 & 71.6 & 73.2 & 74.0 & 75.1 \\
\hline andradite & 2.7 & 2.2 & 2.1 & 2.0 & 3.1 & 0.6 & 1.3 & 0.9 & 0 & 0.9 & 0.7 & 1.2 & 0 \\
\hline grossular & 1.1 & 2.9 & 3.1 & 15.5 & 14.6 & 3.4 & 2.7 & 2.1 & 3.7 & 3.1 & 3.2 & 1.9 & 3.3 \\
\hline pyrope & 8.5 & 18.4 & 13.3 & 3.7 & 4.0 & 25.0 & 24.9 & 20.4 & 22.5 & 9.3 & 15.0 & 13.0 & 12.6 \\
\hline spessartine & 7.5 & 4.5 & 7.2 & 7.4 & 6.9 & 2.1 & 1.7 & 5.5 & 2.5 & 14.9 & 7.6 & 9.7 & 8.5 \\
\hline uvarovite & 0 & 0 & 0 & 0 & 0 & 0.2 & 0.3 & 0.3 & 0.3 & 0.3 & 0.2 & 0.2 & 0.4 \\
\hline
\end{tabular}

Note: $\mathrm{TiO}_{2}, \mathrm{~K}_{2} \mathrm{O}, \mathrm{Na}_{2} \mathrm{O}$-below detection limit. OK-6-from garnet amphibolite, OK-7—from diorite gneiss. 
In both rock types, the rims of the garnet grains were less magnesian than their cores. Garnets from porphyroblasts in gneisses were more magnesian and less ferrian than garnets from amphibolites.

The garnet grains from the porphyroblasts contained a $\mathrm{Cr}$ admixture $\left(<0.1 \% \mathrm{Cr}_{2} \mathrm{O}_{3}\right)$, which was not seen in the garnet from garnet amphibolite (Table 3).

\subsection{Petrochemical Description of the DW Rocks}

During the field observations, it became clear that there were both gneisses and amphibolites among the DW rocks as boudins and extensive beds and lenses. The presence of amphibolites among the gneisses is common, for example, for the West-Karelian subprovince (covering part of eastern Finland and, in Russia, western Karelia and the southwestern border of the Kola Peninsula) where amphibolites are found everywhere in the tonalite-trondhjemite-granodiorite rocks (TTG), usually as layers and inclusions for which width varies from a few dozens of centimeters to dozens of meters [21].

The chemical rock analysis showed that the $\mathrm{SiO}_{2}$ content in many samples was less than $60 \mathrm{wt}$ $\%$. On the TAS (total alkali-silica) diagram (Figure 9), the points for the DW samples lie in the fields of gabbro-diorites, diorites, and granodiorites. The Gabbro-10 metadiorites are classified as granodiorites in the diagram. Samples from borehole 1883 demonstrated a wide compositional scatter from monzonite to granodiorite and granite.

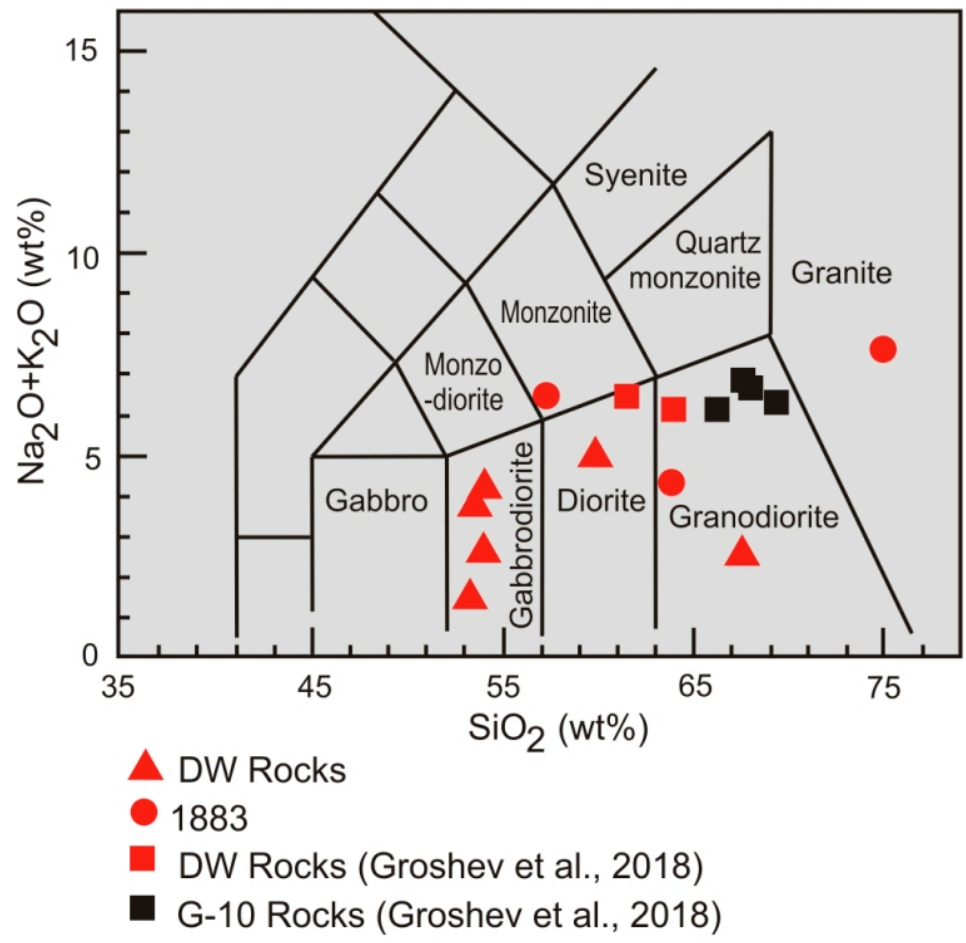

Figure 9. The rocks from the DW block, drill hole 1883, and the Gabbro-10 massif (G-10) in the TAS (total alkali-silica) diagram for plutonic rocks proposed by Middlemost [22].

The majority of the DW rocks and two of three samples from borehole 1883 belonged to a low-potassium series (Figure 10a). Sample 1883/653.1, with a $\mathrm{K}_{2} \mathrm{O} / \mathrm{Na}_{2} \mathrm{O}$ ratio of 0.76 , differed from the other samples from the same borehole in a stronger metamorphic alteration and in a distinctly higher microcline content. The majority of the Gabbro-10 metadiorite samples (three of four) show a $\mathrm{K}_{2} \mathrm{O} / \mathrm{Na}_{2} \mathrm{O}$ ratio $>0.5$. As is obvious from [13], the Gabbro-10 metadiorites were intensively metasomatically modified. 

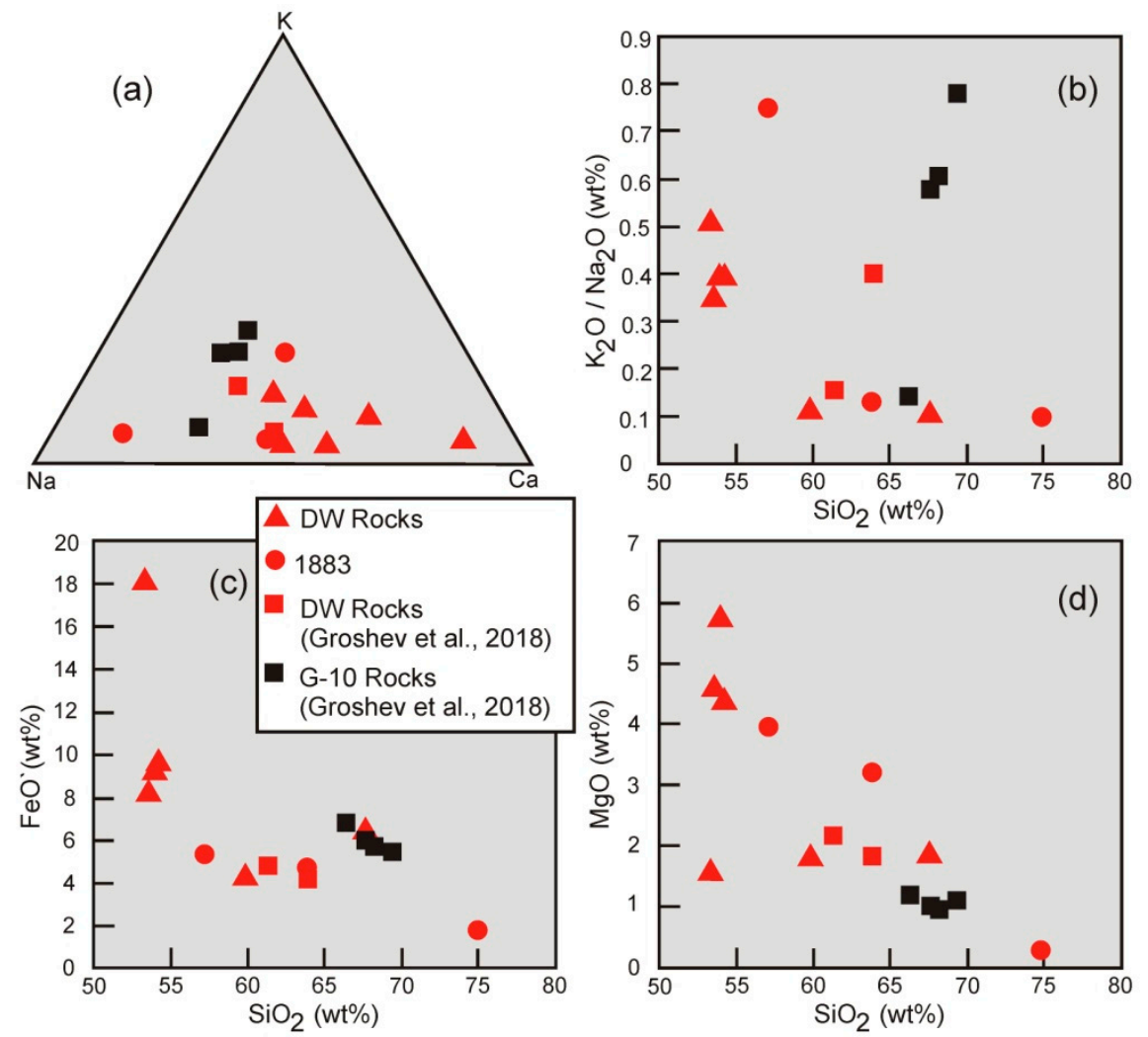

Figure 10. The rocks from the DW block, drill hole 1883, and the Gabbro-10 (G-10) massif in the triangular K-Na-Ca diagram (a) and binary diagrams (b,c,d).

The $\mathrm{Cu}, \mathrm{Ni}$, and Co content in the DW rocks and gneisses from borehole 1883, in addition to in the Gabbro-10 metadiorites, was very low (Table 4). The highest content of ore components was observed in Sample OK-6 (Cu 0.07; Ni 0.016; and Co 0.011 wt \%), which represents garnet amphibolite with a high content of magnetite. This sample differed from the others in high iron content (Figure 10c). The iron and magnesium content of the Gabbro-10 metadiorites was very low (Figure $10 \mathrm{c}, \mathrm{d}$ ).

Groshev and coauthors [13] demonstrated that the distribution of trace elements in the Gabbro-10 metadiorites and Archean basement diorites significantly differs. This concerns a relative enrichment in multicharged ( $\mathrm{Y}, \mathrm{Zr}, \mathrm{Nb}$, and $\mathrm{Ta})$ and heavy rare earth elements for Gabbro-10 metadiorites compared to the Archean gneisses. The chondrite-normalized rare earth elements (REE) distribution patterns (Figure 11) show that the Gabbro-10 metadiorites varied with respect to the basement rocks in a flatter pitch of the curve and occurrence of a slight negative Eu anomaly.

The incompatible-element spider diagram (Figure 11b) and data from Table 5 show that the DW rocks and gneiss from borehole 1883 corresponded well to the average values for the Archean TTGs mentioned in [23] in terms of several elements. However, there was a significant difference in terms of other elements ( $\mathrm{Zr}$ and Hf). Incidentally, [21] provides numerous data on the distribution of trace elements in the basement rock compositions from Western Karelia, which indicate a significant scatter among these rocks. Furthermore, considering the great variety of the Archean grey gneiss compositions widely covered by previous research [21,24-26], it has to be recognized that the rocks of the DW and basement underlying the Monchepluton correspond to diorites and gabbro-diorites. 
Table 4. Chemical composition of rocks of the DW block, borehole 1883, and Gabbro-10 massif (wt \%).

\begin{tabular}{|c|c|c|c|c|c|c|c|c|c|c|c|c|c|c|c|c|}
\hline $\begin{array}{l}\text { Consecu } \\
\text { Number }\end{array}$ & ive 1 & 2 & 3 & 4 & 5 & 6 & 7 & 8 & 9 & 10 & 11 & 12 & 13 & 14 & 15 & 16 \\
\hline Sample & OK 5a & OK 5b & OK 6 & OK 7 & OK 8 & OK 9 & 8 & 9 & OK 10 & $\begin{array}{l}1883 / \\
631.2\end{array}$ & $\begin{array}{l}1883 / \\
653.1\end{array}$ & $\begin{array}{l}1883 / \\
733.6\end{array}$ & 1 & 2 & 3 & 4 \\
\hline $\mathrm{SiO}_{2}$ & 53.89 & 53.52 & 53.30 & 59.82 & 54.16 & 67.60 & 63.87 & 61.33 & 91.71 & 74.92 & 57.14 & 63.81 & 67.64 & 68.15 & 69.39 & 66.27 \\
\hline $\mathrm{TiO}_{2}$ & 0.89 & 1.05 & 0.43 & 0.41 & 1.19 & 0.55 & 0.78 & 0.7 & $<0.01$ & 0.03 & 0.65 & 0.58 & 0.62 & 0.62 & 0.76 & 0.85 \\
\hline $\mathrm{Al}_{2} \mathrm{O}_{3}$ & 17.06 & 20.03 & 10.06 & 19.94 & 18.10 & 12.84 & 17.38 & 17.8 & 2.80 & 12.86 & 17.92 & 16.22 & 12.62 & 12.12 & 11.92 & 11.95 \\
\hline $\mathrm{Cr}_{2} \mathrm{O}_{3}$ & 0.045 & 0.032 & $<0.005$ & 0.079 & 0.038 & 0.032 & b.d.l. & 0.007 & 0.030 & 0.049 & 0.02 & $<0.006$ & 0.007 & 0.007 & b.d.l. & b.d.l. \\
\hline $\mathrm{V}_{2} \mathrm{O}_{5}$ & 0.037 & 0.058 & 0.12 & $<0.025$ & 0.040 & $<0.025$ & 0.025 & b.d.l. & 0.010 & 0.036 & 0.054 & 0.049 & b.d.l. & b.d.l. & 0.02 & 0.011 \\
\hline $\mathrm{Fe}_{2} \mathrm{O}_{3}$ & 2.57 & 2.09 & 6.77 & 1.08 & 2.70 & 1.14 & 1.59 & 1.37 & 0.00 & 0.00 & 2.05 & 1.15 & 3.34 & 3.18 & 2.6 & 2.94 \\
\hline $\mathrm{FeO}$ & 6.95 & 6.35 & 12.02 & 3.35 & 7.07 & 5.41 & 3.06 & 3.57 & 1.82 & 1.76 & 3.52 & 3.71 & 3.01 & 2.87 & 3.16 & 4.2 \\
\hline $\mathrm{MnO}$ & 0.12 & 0.077 & 0.24 & 0.056 & 0.14 & 0.062 & 0.05 & 0.05 & 0.021 & 0.022 & 0.073 & 0.064 & 0.1 & 0.1 & 0.12 & 0.1 \\
\hline $\mathrm{MgO}$ & 5.73 & 4.58 & 1.56 & 1.82 & 4.39 & 1.84 & 1.84 & 2.18 & 0.12 & 0.28 & 3.94 & 3.2 & 0.98 & 0.94 & 1.07 & 1.16 \\
\hline $\mathrm{CaO}$ & 5.27 & 4.15 & 9.03 & 5.49 & 3.38 & 4.16 & 3.55 & 5.59 & 0.82 & 1.53 & 4.85 & 4.03 & 2.54 & 3.13 & 2.89 & 3.08 \\
\hline $\mathrm{Na}_{2} \mathrm{O}$ & 1.86 & 2.73 & 0.93 & 4.55 & 2.96 & 2.33 & 4.39 & 4.86 & 1.01 & 6.87 & 3.76 & 3.68 & 4.28 & 4.15 & 3.56 & 5.4 \\
\hline $\mathrm{K}_{2} \mathrm{O}$ & 0.73 & 0.95 & 0.47 & 0.48 & 1.16 & 0.24 & 1.74 & 0.77 & 0.27 & 0.68 & 2.84 & 0.49 & 2.48 & 2.52 & 2.78 & 0.76 \\
\hline $\mathrm{H}_{2} \mathrm{O}^{-}$ & 0.29 & 0.29 & 0.16 & 0.20 & 0.33 & 0.16 & 0.24 & 0.22 & 0.06 & 0.15 & 0.26 & 0.23 & 0.28 & 0.26 & 0.2 & 0.14 \\
\hline LOI & 4.30 & 3.45 & 2.34 & 1.75 & 3.41 & 2.00 & 1.36 & 1.54 & 0.55 & 0.65 & 2.22 & 0.94 & 1.31 & 1.29 & 1.00 & 1.38 \\
\hline $\mathrm{P}_{2} \mathrm{O}_{5}$ & 0.17 & 0.08 & 0.34 & 0.05 & 0.05 & 0.08 & n.d. & n.d. & 0.01 & 0.02 & 0.19 & 0.17 & 0.2 & 0.19 & 0.18 & 0.21 \\
\hline F & 0.036 & 0.039 & 0.031 & 0.015 & 0.033 & 0.014 & n.d. & n.d. & 0.004 & n.d. & n.d. & n.d. & n.d. & n.d. & n.d. & n.d. \\
\hline $\mathrm{Cl}$ & 0.027 & 0.032 & 0.55 & 0.019 & 0.058 & 0.047 & n.d. & n.d. & 0.026 & 0.01 & 0.012 & 0.011 & n.d. & n.d. & n.d. & n.d. \\
\hline $\mathrm{Cu}$ & $<0.01$ & $<0.01$ & 0.07 & $<0.01$ & $<0.01$ & 0.014 & n.d. & n.d. & $<0.01$ & $\leq 0.01$ & $\leq 0.01$ & $\leq 0.01$ & n.d. & n.d. & n.d. & n.d. \\
\hline $\mathrm{Ni}$ & 0.013 & 0.014 & 0.016 & 0.013 & 0.014 & 0.012 & n.d. & n.d. & 0.015 & $\leq 0.01$ & 0.012 & 0.014 & n.d. & n.d. & n.d. & n.d. \\
\hline Co & $<0.01$ & $<0.01$ & 0.011 & $<0.01$ & $<0.01$ & $<0.01$ & n.d. & n.d. & $<0.01$ & $\leq 0.01$ & $\leq 0.01$ & $\leq 0.01$ & n.d. & n.d. & n.d. & n.d. \\
\hline $\mathrm{CO}_{2}$ & 0.33 & $\leq 0.01$ & 0.31 & $\leq 0.1$ & $\leq 0.1$ & $\leq 0.1$ & b.d.l. & 0.1 & 0.10 & 0.28 & 0.18 & 1.28 & b.d.l. & b.d.l. & b.d.l. & 0.83 \\
\hline$S_{\text {total }}$ & 0.06 & 0.05 & 1.70 & 0.10 & 0.14 & 0.51 & 0.04 & 0.03 & 0.07 & 0.05 & 0.02 & 0.01 & 0.06 & 0.04 & 0.1 & 0.22 \\
\hline Total & 100.38 & 99.57 & 100.44 & 99.22 & 99.36 & 99.04 & 99.91 & 100.12 & 99.45 & 99.9 & 99.71 & 99.64 & 99.47 & 99.57 & 99.75 & 99.50 \\
\hline
\end{tabular}

1-9—rocks of the DW target; 10-12—rocks from drill hole 1883; 13-16—rocks of the Gabbro-10 massif [13]. b.d.l.—below detection limit; n.d.—not determined; LOI—loss on ignition. 
Table 5. Element concentration (ppm) in DW gneiss and metadiorite of the Gabbro-10 massif and borehole 1883.

\begin{tabular}{|c|c|c|c|c|c|c|c|c|c|c|c|}
\hline \multirow[b]{2}{*}{ Sample } & \multirow[b]{2}{*}{8} & \multirow{2}{*}{$\begin{array}{c}\text { Gneiss } \\
9\end{array}$} & \multicolumn{3}{|c|}{ Metadiorite } & \multirow[b]{2}{*}{ Sample } & \multicolumn{3}{|c|}{ Gneiss } & \multicolumn{2}{|c|}{ Metadiorite } \\
\hline & & & & 3 & 4 & & 8 & 9 & & 3 & 4 \\
\hline & $1809 / 58.1$ & $1810 / 62.8$ & $1883 / 653.1$ & 1810/11.1 & $1810 / 18.3$ & & $1809 / 58.1$ & $1810 / 62.8$ & $1883 / 653.1$ & 1810/11.1 & $1810 / 18.3$ \\
\hline $\mathrm{Li}$ & 11.53 & 4.38 & 23.29 & 8.16 & 3.23 & $\mathrm{Ba}$ & 675.23 & 426.61 & 843.04 & 640.60 & 254.71 \\
\hline $\mathrm{Be}$ & 0.65 & 0.46 & 1.17 & 1.03 & 0.79 & $\mathrm{La}$ & 33.27 & 26.31 & 28.12 & 32.83 & 31.81 \\
\hline Sc & 5.31 & 6.47 & 14.30 & 13.31 & 13.67 & $\mathrm{Ce}$ & 60.90 & 49.98 & 59.25 & 69.03 & 69.17 \\
\hline $\mathrm{Ti}$ & 2758.81 & 2959.95 & 2879.26 & 2996.12 & 3137.96 & $\operatorname{Pr}$ & 6.74 & 5.53 & 7.32 & 8.22 & 8.36 \\
\hline $\mathrm{V}$ & 62.52 & 81.75 & 105.67 & 46.57 & 20.17 & $\mathrm{Nd}$ & 23.56 & 19.53 & 28.01 & 30.21 & 32.36 \\
\hline $\mathrm{Cr}$ & 40.54 & 47.18 & 125.67 & 18.41 & 44.26 & $\mathrm{Sm}$ & 3.64 & 2.95 & 4.99 & 5.64 & 6.23 \\
\hline $\mathrm{Mn}$ & 295.75 & 310.93 & 399.60 & 768.36 & 671.06 & $\mathrm{Eu}$ & 0.97 & 0.87 & 1.30 & 1.25 & 1.59 \\
\hline $\mathrm{Co}$ & 10.99 & 14.17 & 18.77 & 11.08 & 13.85 & $\mathrm{Gd}$ & 2.13 & 1.85 & 3.14 & 4.65 & 5.87 \\
\hline $\mathrm{Ni}$ & 27.51 & 41.13 & 64.88 & 18.29 & 22.33 & $\mathrm{~Tb}$ & 0.25 & 0.20 & 0.40 & 0.72 & 0.93 \\
\hline $\mathrm{Cu}$ & 22.52 & 53.64 & 8.97 & 43.40 & 100.50 & Dy & 1.14 & 0.89 & 2.25 & 4.39 & 5.75 \\
\hline $\mathrm{Zn}$ & 59.82 & 58.85 & 54.90 & 58.69 & 35.01 & Ho & 0.18 & 0.15 & 0.41 & 0.91 & 1.21 \\
\hline $\mathrm{Ga}$ & 20.18 & 22.61 & 18.30 & 15.55 & 15.70 & $\mathrm{Er}$ & 0.42 & 0.37 & 1.07 & 2.66 & 3.64 \\
\hline $\mathrm{Ge}$ & 0.59 & 0.57 & 1.14 & 1.05 & 0.97 & $\mathrm{Tm}$ & 0.05 & 0.05 & 0.15 & 0.37 & 0.51 \\
\hline $\mathrm{Rb}$ & 34.46 & 15.94 & 90.66 & 74.35 & 21.51 & $\mathrm{Yb}$ & 0.28 & 0.25 & 0.97 & 2.30 & 3.17 \\
\hline $\mathrm{Sr}$ & 432.02 & 494.52 & 493.84 & 210.24 & 265.57 & $\mathrm{Lu}$ & 0.04 & 0.03 & 0.13 & 0.32 & 0.45 \\
\hline $\mathrm{Y}$ & 4.45 & 4.46 & 10.36 & 24.00 & 32.00 & $\mathrm{Hf}$ & 2.01 & 1.65 & 0.94 & 3.00 & 3.89 \\
\hline $\mathrm{Zr}$ & 75.65 & 81.76 & 23.60 & 117.80 & 148.18 & $\mathrm{Ta}$ & 0.23 & 0.21 & 0.28 & 0.56 & 0.57 \\
\hline $\mathrm{Nb}$ & 2.30 & 2.64 & 4.88 & 7.42 & 8.51 & W & n.d. & n.d. & 0.40 & n.d. & n.d. \\
\hline Mo & 1.57 & 2.30 & 1.79 & 2.28 & 6.50 & $\mathrm{Tl}$ & 0.16 & 0.06 & 0.45 & 0.33 & 0.13 \\
\hline $\mathrm{Ag}$ & 0.07 & 0.09 & 0.08 & 0.22 & 0.26 & $\mathrm{~Pb}$ & 10.84 & 7.98 & 12.14 & 14.26 & 9.09 \\
\hline $\mathrm{Cd}$ & n.d. & n.d. & 0.04 & 0.06 & n.d. & $\mathrm{Bi}$ & 0.03 & 0.01 & 0.05 & 0.07 & 0.04 \\
\hline Sn & 0.89 & 1.72 & 1.24 & 1.67 & 3.17 & Th & 9.54 & 7.60 & 5.79 & 7.57 & 6.01 \\
\hline $\mathrm{Sb}$ & 0.04 & 0.08 & 0.03 & 0.06 & 0.12 & $\mathrm{U}$ & 0.88 & 0.59 & 0.89 & 1.79 & 1.58 \\
\hline $\mathrm{Te}$ & 0.01 & 0.00 & 0.01 & 0.02 & 0.01 & As & 0.66 & 0.99 & n.d. & 0.92 & 0.83 \\
\hline Cs & 1.74 & 1.59 & 2.80 & 1.01 & 1.78 & & & & & & \\
\hline
\end{tabular}




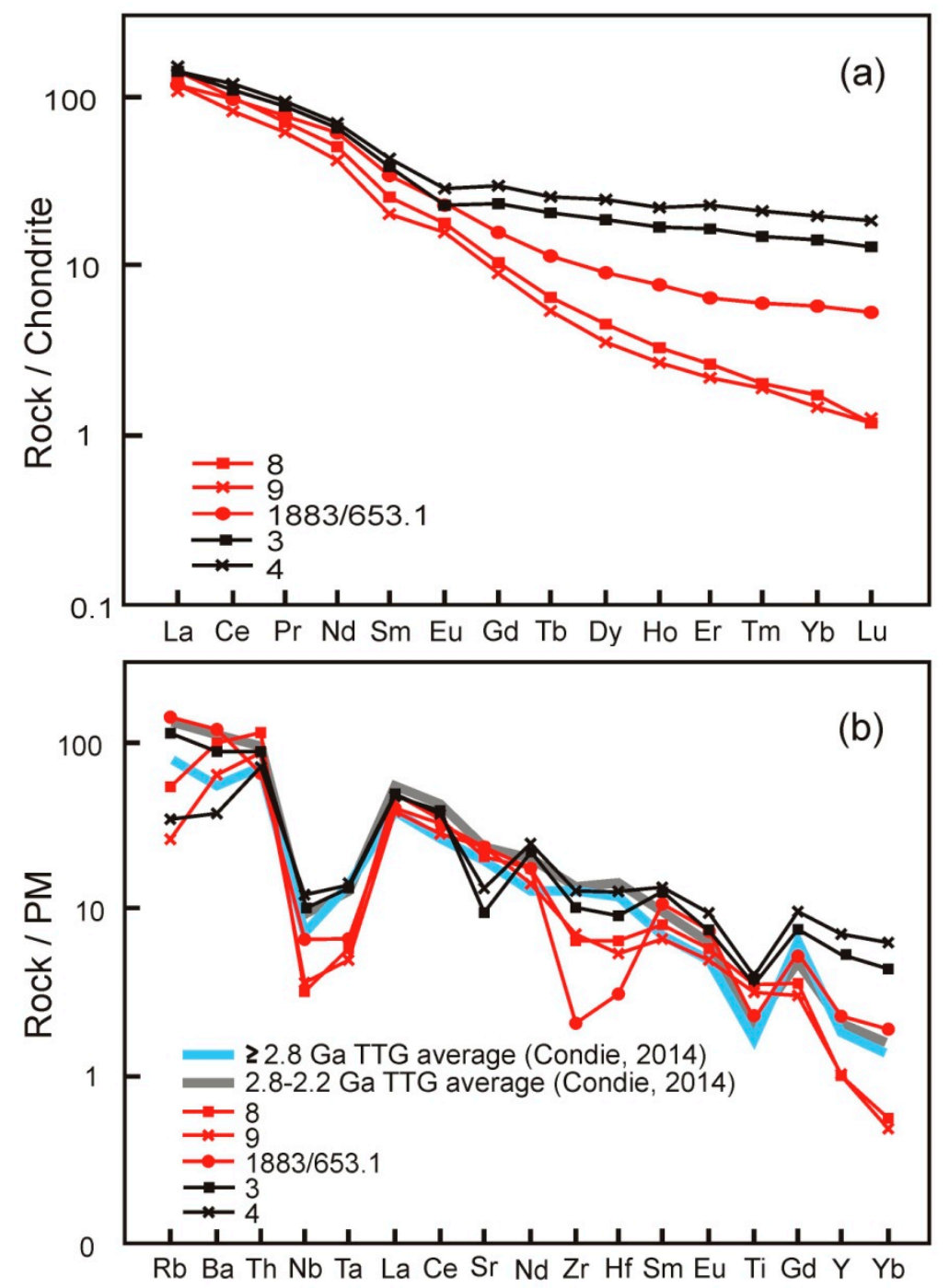

Figure 11. Chondrite normalized rare earth element patterns (a) and the primitive mantle normalized trace element diagram (b) for diorite-gneisses from the DW block, gneiss from the borehole 1883, metadiorite of the Gabbro-10 massif, and average data for tonalite-trondhjemite-granodiorite rocks (TTG) [23]. Normalization factors from [27,28]. Numbers 3, 4, 8, and 9 (see Table 5) are from the literature [13].

The difference between DW rocks and Gabbro-10 metadiorites is that heavy rare earth elements were weakly fractionated in metadiorites (Gabbro-10) and highly fractionated in diorite gneisses (DW). The REE spectra of the Gabbro-10 metadiorites show weak negative Eu anomalies. Spider diagrams show the depletion of all rocks in $\mathrm{Nb}, \mathrm{Ta}, \mathrm{Zr}, \mathrm{Hf}$, and Ti. These features were more pronounced in the diorite gneisses of the DW. The metadiorites of Gabbro- 10 were characterized by a negative Sr anomaly. Thus, the rocks of the DW and metadiorites of Gabbro-10 massif differed from the rocks of the TTG association. Differences between the DW diorites and the Gabbro-10 metadiorites were also noted in terms of both major and trace elements.

\subsection{Ore Mineralization}

The studied samples of diorite-gneisses and amphibolites contained irregular oxide-sulfide impregnation with ore mineral concentrations varying from $0.5 \%$ to $2 \%$.

Sulfides were represented by pyrite, pyrrhotite, and chalcopyrite. They mainly formed single and predominantly anhedral grains and intergrowths with a size of up to $1 \mathrm{~mm}$ composed of pyrite, 
pyrrhotite, and chalcopyrite. The contents of ore generating elements in the rocks are of no commercial interest. For example, the garnet amphibolite (Sample OK-6) had the following metal contents (ppm): $\mathrm{Cu}-0.07 ; \mathrm{Ni}-0.016$; $\mathrm{Co}-0.011 ; \mathrm{Au}-0.030$; and $\mathrm{Ag}-0.180$.

Oxides in the gneisses and amphibolites were represented by ilmenite and goethite. Ilmenite formed small elongated and anhedral grains with a length of up to $0.1 \mathrm{~mm}$, which were mainly tightly intergrown with biotite plates. Goethite occurred as either single anhedral grains with indented edges or aggregates.

Individual thin zones with sulfide pyritic mineralization were also found at great depths $(635-700 \mathrm{~m})$ in fine-grained diorite-gneisses penetrated by vertical borehole 1883 [29].

\subsection{Geochronology of the DW Rocks}

\subsubsection{U-Pb Zircon Geochronology}

The diorite-gneiss (Sample OK-15) was chosen for age determination. The rock consisted of plagioclase, biotite, and quartz with minor chlorite, actinolite, epidote, and ilmenite. The sample weighted $9 \mathrm{~kg}$. The separated zircon grains were light-brown colored, had an elongated-prismatic shape, and had even and smooth contours (Figure 12). Suspected old cores were observed in many zircon crystals. Thin oscillatory zoning was intrinsic for the majority of the crystals.

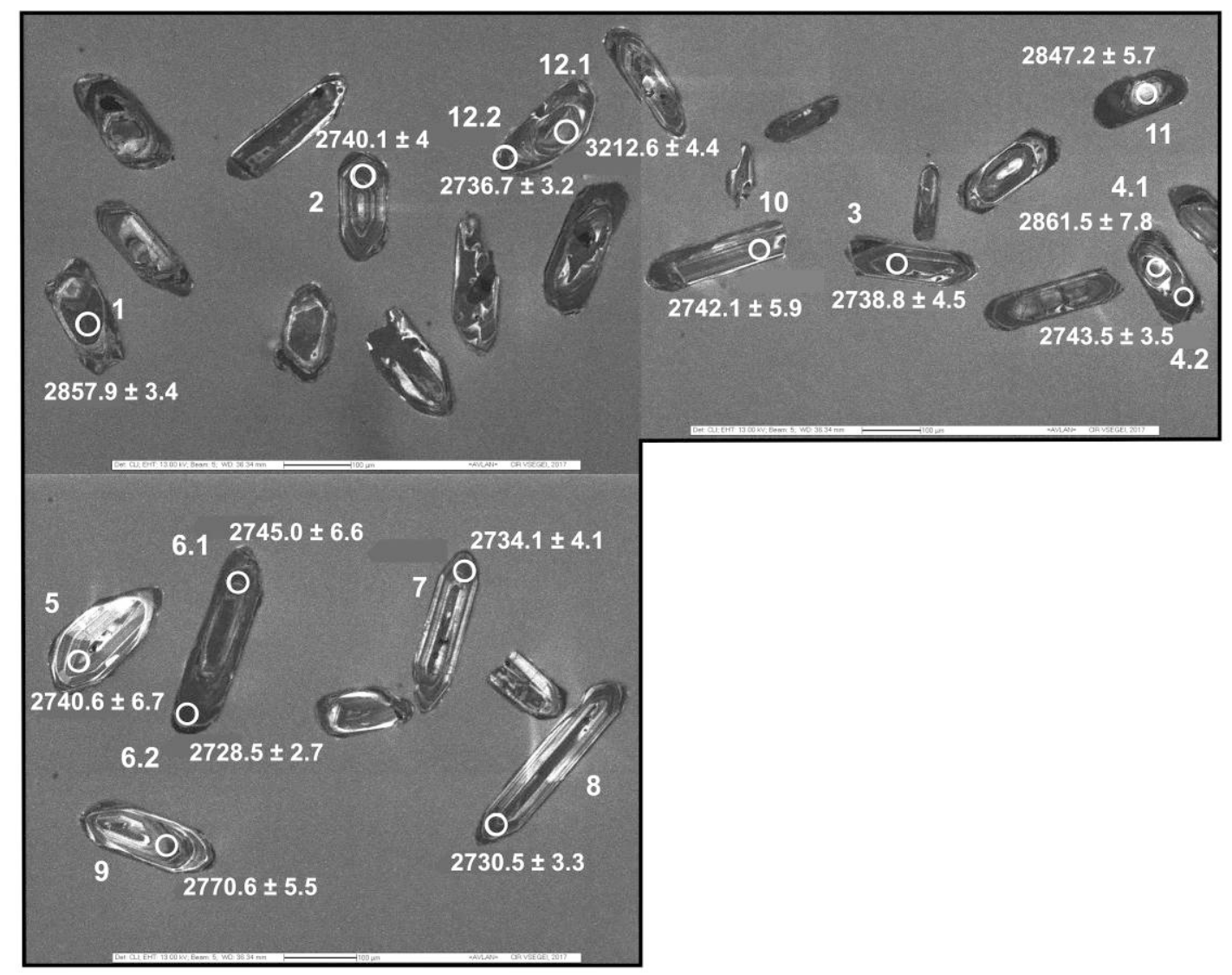

Figure 12. Cathodoluminescent images and age of zircons from rocks of the DW block.

The age of the zircons was determined by a SHRIMP-II method on 15 points; the data are shown in Table 6 and Figure 13. The age determination on eight zircon points showed a U-Pb Concordia Age of $2736 \pm 11 \mathrm{Ma}$. Older ages were found in several points for the core zircon parts. An age of about 2856 Ma was defined for three grains and an even older age of 3213 Ma was established for one grain. 
Table 6. Isotopic $\mathrm{U}-\mathrm{Pb}$ data for zircons from OK-15 sample (diorite-gneiss from the DW block).

\begin{tabular}{|c|c|c|c|c|c|c|c|c|c|c|c|c|c|c|c|c|c|}
\hline Spot & ${ }^{206} \mathrm{~Pb}_{\mathrm{c}}$ & $\underset{\mathrm{Upm}}{\mathrm{Ppm}}$ & $\begin{array}{c}\text { Ppm } \\
\text { Th }\end{array}$ & $\begin{array}{l}{ }^{232} \mathrm{Th} \\
{ }^{238} \mathrm{U}\end{array}$ & $\underset{{ }^{206} \mathrm{~Pb}^{*}}{\mathrm{Ppm}}$ & $\begin{array}{c}(1)^{206} \mathrm{~Pb} \\
{ }^{238} \mathrm{U} \text { Age }\end{array}$ & $\begin{array}{c}(1) \\
{ }^{207} \mathrm{~Pb} /{ }^{206} \mathrm{~Pb} \\
\text { Age }\end{array}$ & $\begin{array}{c}\% \\
\text { Discor } \\
\text { dance }\end{array}$ & $\begin{array}{c}(1) \\
{ }^{238} \mathrm{U} /{ }^{206} \mathrm{~Pb}^{*}\end{array}$ & $\pm \%$ & \multicolumn{2}{|c|}{$\underset{{ }^{207} \mathbf{P b}^{*} / p^{206} \mathbf{P b}^{*}}{ }{ }^{{ }^{ \pm} \%}$} & $\begin{array}{c}\text { (1) } \\
{ }^{207} \mathrm{~Pb}^{*} / 235 \mathrm{U}\end{array}$ & $\pm \%$ & $\begin{array}{c}(1) \\
{ }^{206} \mathrm{~Pb}^{*} /^{238} \mathrm{U}\end{array}$ & $\pm \%$ & Rho \\
\hline OK15_1.1 & 0.02 & 558 & 107 & 0.2 & 264 & $2829 \pm 34$ & $2857.9 \pm 3.4$ & 1 & 1.815 & 1.5 & 0.20392 & 0.21 & 15.49 & 1.5 & 0.5509 & 1.5 & 0.991 \\
\hline OK15_2.1 & 0.05 & 405 & 291 & 0.74 & 180 & $2691 \pm 31$ & $2740.1 \pm 4$ & 2 & 1.93 & 1.4 & 0.18976 & 0.25 & 13.56 & 1.4 & 0.5181 & 1.4 & 0.985 \\
\hline OK15_3.1 & 0.01 & 343 & 329 & 0.99 & 148 & $2621 \pm 31$ & $2738.8 \pm 4.5$ & 4 & 1.993 & 1.4 & 0.18962 & 0.27 & 13.12 & 1.5 & 0.5017 & 1.4 & 0.982 \\
\hline OK15_4.1 & 0.09 & 111 & 47 & 0.44 & 50.9 & $2749 \pm 34$ & $2861.5 \pm 7.8$ & 4 & 1.88 & 1.5 & 0.20438 & 0.48 & 14.99 & 1.6 & 0.5318 & 1.5 & 0.953 \\
\hline OK15_5.1 & 0.03 & 147 & 81 & 0.57 & 68.1 & $2779 \pm 33$ & $2740.6 \pm 6.7$ & -1 & 1.856 & 1.5 & 0.18982 & 0.41 & 14.1 & 1.5 & 0.5388 & 1.5 & 0.964 \\
\hline OK15_4.2 & 0 & 536 & 489 & 0.94 & 244 & $2738 \pm 31$ & $2743.5 \pm 3.5$ & 0 & 1.889 & 1.4 & 0.19016 & 0.21 & 13.88 & 1.4 & 0.5292 & 1.4 & 0.989 \\
\hline OK15_6.1 & 0.05 & 601 & 359 & 0.62 & 323 & $3131 \pm 42$ & $2745 \pm 6.6$ & -12 & 1.599 & 1.7 & 0.19033 & 0.4 & 16.41 & 1.8 & 0.625 & 1.7 & 0.973 \\
\hline OK15_7.1 & 0.01 & 385 & 244 & 0.65 & 174 & $2724 \pm 31$ & $2734.1 \pm 4.1$ & 0 & 1.902 & 1.4 & 0.18907 & 0.25 & 13.71 & 1.4 & 0.5258 & 1.4 & 0.985 \\
\hline OK15_8.1 & 0.01 & 640 & 396 & 0.64 & 295 & $2771 \pm 32$ & $2730.5 \pm 3.3$ & -1 & 1.862 & 1.4 & 0.18866 & 0.2 & 13.97 & 1.4 & 0.537 & 1.4 & 0.99 \\
\hline OK15_9.1 & 0.04 & 218 & 126 & 0.6 & 97.1 & $2693 \pm 32$ & $2770.6 \pm 5.5$ & 3 & 1.929 & 1.5 & 0.19332 & 0.33 & 13.82 & 1.5 & 0.5185 & 1.5 & 0.974 \\
\hline OK15_6.2 & 0.01 & 899 & 33 & 0.04 & 416 & $2779 \pm 32$ & $2728.5 \pm 2.7$ & -2 & 1.856 & 1.4 & 0.18843 & 0.17 & 14 & 1.4 & 0.5389 & 1.4 & 0.993 \\
\hline OK15_10.1 & 10.06 & 202 & 157 & 0.8 & 88.7 & $2664 \pm 32$ & $2742.1 \pm 5.9$ & 3 & 1.954 & 1.5 & 0.18999 & 0.36 & 13.4 & 1.5 & 0.5117 & 1.5 & 0.971 \\
\hline OK15_11.1 & 10.06 & 169 & 85 & 0.52 & 90.3 & $3112 \pm 36$ & $2847.2 \pm 5.7$ & -9 & 1.611 & 1.5 & 0.20259 & 0.35 & 17.34 & 1.5 & 0.6206 & 1.5 & 0.972 \\
\hline OK15_12.1 & 10.03 & 203 & 82 & 0.42 & 114 & $3248 \pm 37$ & $3212.6 \pm 4.4$ & -1 & 1.527 & 1.4 & 0.25443 & 0.28 & 22.98 & 1.5 & 0.6551 & 1.4 & 0.981 \\
\hline OK15_12.2 & $2 \quad 0.03$ & 686 & 942 & 1.42 & 315 & $2764 \pm 32$ & $2736.7 \pm 3.2$ & -1 & 1.868 & 1.4 & 0.18937 & 0.2 & 13.98 & 1.4 & 0.5355 & 1.4 & 0.99 \\
\hline
\end{tabular}

Errors are 1-sigma; $\mathrm{Pb}_{\mathrm{c}}$ and $\mathrm{Pb}^{*}$ indicate the common and radiogenic portions, respectively. Error in the standard calibration was $0.51 \%$ (not included in above errors but required when comparing data from different mounts). (1) Common $\mathrm{Pb}$ corrected using measured ${ }^{204} \mathrm{~Pb}$. Rho, coefficient of correlation. 

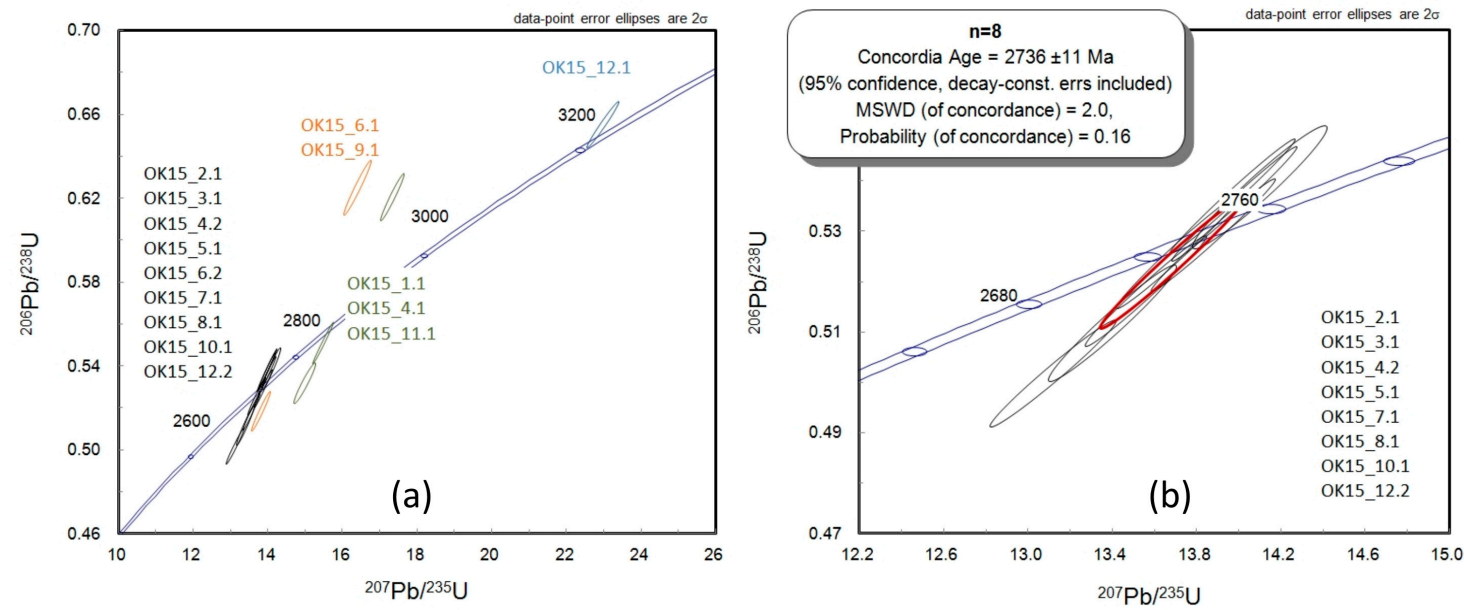

Figure 13. U-Pb isotopic data for zircons from OK-15 sample (DW block): (a), all grains measured and (b), grains involved in age calculation.

\subsubsection{Sm-Nd Geochronology}

Pure tourmaline (Sample OK-8) fractions from the tourmaline schlieren in the diorite-gneisses, and biotite and garnet (Sample OK-7) ones from the garnet porphyroblasts with a complex composition were separated for age determination. Tourmaline is represented by prismatic black-colored crystals with a vitreous luster and striation on the side faces. Biotite formed lamellar dark-grey-colored crystals. The garnet fraction was divided into four parts during the electromagnetic separation. Four garnet varieties differing in electromagnetic properties and color from white-pink to bright-pink were obtained and analyzed separately. The results are given in Figure 14 and Table 7.

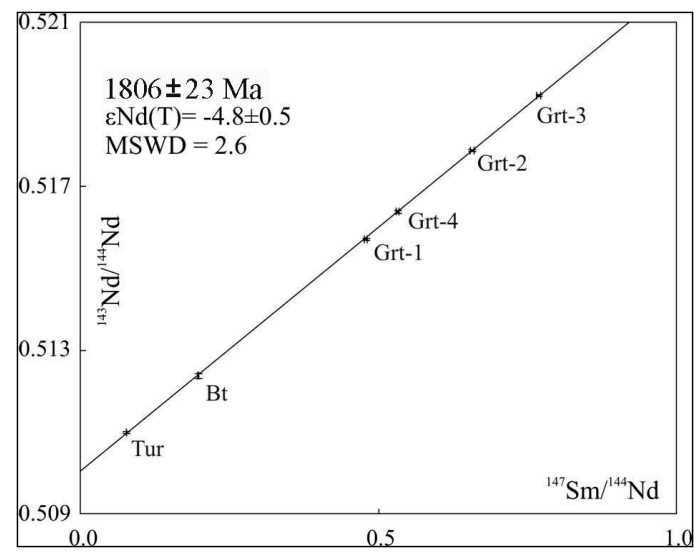

Figure 14. Sm-Nd isotopic data for garnet (Grt)-tourmaline (Tur)-biotite (Bt) from diorite-gneiss of the DW block.

Table 7. Sm-Nd isotopic data for minerals from rocks of the DW block.

\begin{tabular}{ccccccc}
\hline \multirow{2}{*}{ Sample } & \multirow{2}{*}{ Mineral } & \multicolumn{2}{c}{ Concentration, ppm } & \multicolumn{2}{c}{ Isotopic Ratio } & \multirow{2}{*}{$\varepsilon_{\mathbf{N d}}(\mathbf{T})$} \\
\cline { 3 - 5 } & & $\mathbf{S m}$ & $\mathbf{N d}$ & ${ }^{\mathbf{1 4 7}} \mathbf{S m} /{ }^{\mathbf{1 4 4}} \mathbf{N d}$ & $\mathbf{1 4 3}^{\mathbf{N d}} /{ }^{\mathbf{1 4 4}} \mathbf{N d}$ & \\
\hline OK-8 & Tourmaline & 2.08 & 16.33 & 0.0771 & $0.510998 \pm 19$ & -4.4 \\
OK-7 & Biotite & 1.506 & 4.60 & 0.1978 & $0.512378 \pm 29$ & -5.4 \\
OK-7 & Garnet-1 & 3.31 & 4.17 & 0.4790 & $0.515701 \pm 18$ & -5.5 \\
OK-7 & Garnet-2 & 3.75 & 3.45 & 0.6575 & $0.517877 \pm 17$ & -4.3 \\
OK-7 & Garnet-3 & 3.54 & 2.78 & 0.7695 & $0.519221 \pm 26$ & -3.9 \\
OK-7 & Garnet-4 & 4.42 & 5.02 & 0.5324 & $0.516383 \pm 29$ & -4.5 \\
\hline
\end{tabular}


The Sm-Nd age determination demonstrated that the metamorphic minerals from schlieren in the diorite-gneisses of the DW were formed $1806 \pm 23$ million years ago.

\section{Discussion}

The investigation of two diorite types related to the Monchegorsk complex showed the following. The diorite-gneisses of the DW represented the Archean basement rocks widespread on the Fennoscandian shield. It could be noted that the Paleoarchean rocks (3.60-3.20 Ga) were seen on the Fennoscandian shield only locally while the Eoarchean or Hadean $(>3.60 \mathrm{Ga})$ rocks were not yet found. However, some Eoarchean-Hadean zircon grains were identified in the Paleoproterozoic and Archean metasedimentary rocks of the Lapland-Kola belt, Kola belt, and Karelia [30]. Some greenstone belts and tonalite-trondhjemite-granodiorite units had an age of 3.1-2.9 Ga, but the majority of Archean shield rocks were $2.8-2.6$ Ga old [31,32].

The difference between DW rocks and Gabbro-10 metadiorites is that heavy rare earth elements were weakly fractionated in metadiorites (Gabbro-10) and highly fractionated in diorite gneisses (DW). The REE spectra of the Gabbro-10 metadiorites show weak negative Eu anomalies, which can be explained by the process of removal of feldspar from a melt by crystal fractionation. This assumption was supported by the negative Sr anomaly for the Gabbro-10 metadiorites in the spider diagram. Spider diagrams also show the depletion of all rocks in $\mathrm{Nb}, \mathrm{Ta}, \mathrm{Zr}, \mathrm{Hf}$, and Ti. These features were more pronounced in the diorite gneisses of the DW.

Both types of the studied diorites, in terms of their composition (from gabbro-diorites to granites), complied with a broad definition of grey gneisses. The zircon cores from the DW rocks probably bear traces of more ancient rock protoliths (about 2.85 and $3.20 \mathrm{Ga}$ ), which are known both in the Kola part of the Baltic shield (Voche-Lambina geological site) and in other Archean regions [33]. The studied zircons had morphological features (growing zonation) of igneous minerals [34] and the Concordia Age (in eight points) of $2736 \pm 11 \mathrm{Ma}$, apparently, corresponded to the age of emplacement of granitoids, which were the immediate protoliths of the DW rocks.

It is notable that a similar age $(2758 \pm 14 \mathrm{Ma})$ was also provided by one of the zircon generations from the Gabbro-10 metadiorites [13]. We believe that such a zircon age (measured in the cores and unaltered part of grains) also corresponds to the age of granitoids, which were protoliths of the Archean basement gneisses. The cores of zircon grains from the metadiorites represent relics of zircons from older rocks.

The U-Pb SHRIMP-II dating of zircon and baddeleyite from the Gabbro-10 metadiorites showed that the age of their magmatic crystallization was $2498 \pm 6$ Ma [13]. This age coincided, within error, with the isotope age of the Nude-Poaz massif that, according to [13], points to a primary intrusive nature of the metadiorites and indicates the affiliation of the related magnetite V-Ti mineralization to the ore-magmatic system of the Monchegorsk pluton [13]. Macroscopically and in terms of major element composition, the metadiorites resembled Archean diorites and diorite-gneisses encompassing the Monchepluton. In particular, it served as a basis for a hypothesis that considers the Gabbro-10 metadiorites as albitized basement rocks [1]. However, some authors believe that low concentrations of heavy REEs in the basement diorites do not allow considering them as a substrate, which metasomatic transformation could lead to the formation of the Gabbro-10 metadiorites [13].

Sm-Nd age determination showed that the metamorphic minerals occurring as extensive schlieren in the DW diorite-gneisses formed $1806 \pm 23$ million years ago, which corresponds to the final stage of the Imandra-Varzuga belt evolution. The age of $1939 \pm 16$ Ma was recorded in one of the zircon generations in the Gabbro-10 metadiorites [13]. These ages were quite reliably tied with the fluid-driven metamorphic processes accompanying the Svecofennian orogeny with an interval of 1.9-1.8 Ga [35,36].

Thus, the available data still allow for making quite general conclusions. The DW rocks (diorite-gneisses and amphibolites) were fitted into a wide term of grey gneisses describing the ancient rocks of the Archean shield basement. The Gabbro-10 metadiorites were not chemically different from the basement rocks except for some differences described in [13]. Nevertheless, combining 
geological and especially geochronological data, their affiliation with later intrusive rocks seems justified. Concerning the interaction with the igneous rocks of the Monchegorsk complex with the basement diorites, the following can be noted.

Within the best exposed part of the DW and closer to the contact with the Sopcha and Nude-Poaz massifs, no significant changes related with the emplacement of the Monchegorsk complex were observed. The oxide and sulfide mineralization of the DW rocks studied in the surface samples revealed no clear relationship to the PGE-Cu-Ni mineralization for various Monchegorsk complex phases. At the same time, $\mathrm{Cu}-\mathrm{Ni}$ ores in the basement diorites are known in the direct contact with the Nude-Poaz massif in accordance with the drilling results [12].

A somewhat different picture is typical of the contact zone between the basement diorite-gneisses and the Gabbro-10 massif.

Near the lower contact of this massif with the underlying Archean rocks, a zone of schistose metagabbroids and igneous breccia is developed. The cement of the breccia is represented by the metadiorites and magnetite rocks; the fragments consist of Archean basement diorite-gneisses where numerous cement veinlets occur. A so-called magnetite layer containing up to 90 vol.\% of magnetite lies at the bottom of the breccia zone [13].

The sulfide PGE-Cu-Ni mineralization associated with the Gabbro-10 massif is also related to its marginal part. It probably formed as a result of the emplacement of an additional magmatic phase saturated with a sulfide liquid. Sulfides concentrated in the lower part of the massif, predominantly in the rocks of the marginal zone, during the gravitational deposition and permeation in the intercumulus space (now, schistose metagabbroides). This process has concerned the underlying Archean diorite-gneisses containing a sulfide mineralization similar to that from the metagabbro [12].

Thus, based on the studied various types of diorites within the Monchegorsk complex (their composition, ore mineralization, age, and relationships with mafic-ultramafic rocks), it was possible to assume the following chain of geological events (Table 8).

Table 8. The sequence of major geological events in the interval 2.8-1.8 Ga in the region of the current position of the Monchegorsk complex.

\begin{tabular}{|c|c|}
\hline Period (Billion Years) & Event \\
\hline $1.9-1.8$ & $\begin{array}{l}\text { Svecofennian orogeny accompanied by tectonic processing and metamorphism of } \\
\text { basement rocks (boudinage, formation of the amphibole-garnet-tourmaline } \\
\text { association). }\end{array}$ \\
\hline $2.5-2.4$ & $\begin{array}{l}2.5-0.002 \mathrm{Ga} \text {-incoming of additional late intrusive phases of the Monchegorsk } \\
\text { complex and their differentiation (gabbronorite-gabbro-diorite), formation of } \\
\text { a magnetite layer of the Gabbro- } 10 \text { massif and sulfide } \mathrm{Cu}-\mathrm{Ni} \text {-PGE deposits, } \\
\text { intensive penetration of sulfide mineralization }(\mathrm{Cu} / \mathrm{Ni}=2) \text { into the basement } \\
\text { diorite. }\end{array}$ \\
\hline & $\begin{array}{l}2.5+0.004 \mathrm{Ga} \text {-incoming of the main intrusive phase of the Monchegorsk } \\
\text { complex (in particular, norite-pyroxenite of the Nude-Poaz massif), formation of } \\
\text { sulfide } \mathrm{Cu}-\mathrm{Ni} \text {-PGE deposits, partial penetration of sulfide mineralization } \\
(\mathrm{Cu} / \mathrm{Ni}=1) \text { into the basement diorite. }\end{array}$ \\
\hline $2.8-2.7$ & $\begin{array}{l}\text { Magmatic crystallization of rocks of the Archean basement and subsequent } \\
\text { metamorphism and migmatization, when diorite-gneisses were formed. }\end{array}$ \\
\hline
\end{tabular}

The magmatic crystallization of the Archean basement rocks (gneisses and diorite-gneisses) took place during a period of ca. 2.8-2.7 Ga during the formation of a mature continental crust [33].

During a period of 2.5-2.4 Ga, these rocks were intruded by the Monchegorsk complex intrusions. It is admitted that the Monchegorsk complex is a polyphase complex. Some isotope data show that, at least, one of the Monchetundra intrusion phases represented by leuco-gabbronorites and gabbro of the South Sopchinsky and Gabbro-10 massifs intruded somewhat later than the massifs in the sublateral branch of the Monchepluton (Sopcha and Nude-Poaz massifs) [37]. 
It may follow that, at the earlier emplacement of the pyroxenite-norite into the country Archean diorites, the influence of these intrusions on the basement rocks was at a minimum. It has also not induced vast processes of transferring ore mineralization to the diorites typical of the mafic-ultramafic intrusions. Therefore, we observed neither typical mineralization, nor corresponding age datings in the DW, were induced by the thermal effect of the Monchegorsk complex phases on the Archean diorite-gneisses. It shall, however, be noted that the process of partial permeation of sulfide mineralization (with $\mathrm{Cu} / \mathrm{Ni}=1$ ) of these rocks was observed in the thin zones of the Nude-Poaz massif endocontact [12].

The units of the Monchetundra intrusion (predominantly gabbro-gabbronorite composition) intruded somewhat later to the zone of the southern contact of the Monchepluton to exert a greater impact on the Archean diorite-gneisses. This was probably related to the fact that this zone had earlier been weakened and permeable. The interaction of these melts with diorite-gneisses, in accordance with one of the hypotheses [1], could yield the Gabbro-10 massif metadiorites. However, we tend to consider these rocks and gabbroids (and the magnetite layer) to be initially igneous rocks. Nevertheless, the influence of these phases on the Archean diorite-gneisses was still quite considerable. It was accompanied by the generation of igneous breccia with numerous fragments of the basement rocks in the metadiorites. The further injection of another subphase saturated with sulfide liquid caused the deposition of sulfides (with PGEs) in the marginal part of the massif and their permeation into the country diorites. This mineralization forms thicker zones in the underlying diorite-gneisses of the basement and shows a ratio of $\mathrm{Cu} / \mathrm{Ni}=2$ [12].

Later, all of the rocks in this zone were subject to metamorphic processes during the Svecofennian orogeny with an age of 1.9-1.8 Ga. At that time, the rocks of the DW underwent boudinage and later minerals of the amphibole-garnet-tourmaline assemblage formed there.

\section{Conclusions}

1. The intermediate (dioritic) composition rocks occurred within the Monchegorsk complex: (1) as a unit of Archean basement rocks in the central part of the intrusion (DW) and (2) as so-called metadiorites within the Gabbro-10 intrusion. In terms of the geological and isotope-geochronological date, it is possible to suggest that the Gabbro-10 metadiorites were not the alteration derivatives of the Archean basement diorite-gneiss and represented one of the latest igneous phases of the Monchegorsk complex.

2. The rocks of the DW differed from the typical TTG association by lesser silica, and larger iron and magnesium contents, and, regarding trace elements, by lower contents of zirconium and hafnium. For DW rocks and Gabbro-10 metadiorites, the overcoming of light rare earth elements (LREE) over the heavy rare earth elements (HREE), negative high field strength elements (HFSE) anomalies, and different degrees of fractionation of heavy REE was observed. This may indicate different sources of their parent magmas.

Isotope-geochemical features corresponded to the most ancient basement rocks developed in the north-eastern part of the Fennoscandian shield. There was not any significant Cu-Ni-PGE mineralization associated with the injection of earlier phases of the Monchegorsk complex in those rocks.

3. The metadiorites of the Gabbro-10 massif associated with Fe-Ti-V mineralization (the so-called magnetite layer) were also of an igneous nature. Younger phases of the Monchegorsk complex (to which the Gabbro-10 massif belongs) intruded into a tectonically weakened zone (controlled by the Monchetundra fault) with the resultant eruptive breccia and intensive permeation of sulfide (with PGE) liquid to the underlying diorite-gneisses of the basement. Unlike the rocks of the DW (contacting with older phases of the Monchegorsk complex), the Cu-Ni-PGE mineralization in the diorite-gneisses underlying the Gabbro-10 massif was more promising in terms of volumes and grade.

4. The Monchegorsk complex rocks and country diorite-gneisses underwent metamorphism, fluid, and tectonic reworking 1.9-1.8 billion years ago. 
Author Contributions: Conceptualization, P.P. and T.R., analyses, methodology-N.G., A.B. and P.S., field research and provision of study materials, P.P. and T.R., investigation, N.G., A.B. and P.S., data curation and validation, P.P and T.R., writing_-original draft, T.R., writing—review and editing, P.P. All authors have read and agreed to the published version of the manuscript. Please confirm modification here.

Funding: This study was financially supported by Russian Foundation for Basic Research, projects No. 18-05-70082 and the state budget research (No. 0226-2019-0053).

Acknowledgments: The authors express gratitude to V.V. Balagansky for valuable advice in the issues of tectonics and geodynamics in the north-eastern part of the Fennoscandian shield and A.N. Kobeleva for the provided files and assistance during the fieldworks. The authors are grateful to the anonymous reviewers, thanks to their comments the content of the article was significantly improved. The authors are also grateful to A.S. Rybnikova for the assistance in the translation of the manuscript into English.

Conflicts of Interest: The authors declare no conflict of interest.

\section{References}

1. Kozlov, E.K. Natural Series of Rocks of the Nickel-Bearing Intrusions and Their Metallogeny; Nauka: Leningrad, Russia, 1973.

2. Yudin, B.A. Gabbro-Labradorite Formation of the Kola Peninsula and Its Metallogeny; Nauka: Leningrad, Russia, 1980.

3. Smolkin, V.F.; Fedotov, Z.A.; Orsoev, D.A.; Ohnenstetter, D. Ore-bearing layered Monchepluton. In Layered Intrusions of the Monchegorsk Ore Region: Petrology, Mineralization, Isotopy, Deep Structure. Part 1; Mitrofanov, F.P., Smolkin, V.F., Eds.; KSC RAS: Apatity, Russia, 2004; pp. 36-75.

4. Bayanova, T. Age of Reference Geological Complexes of the Kola Region and the Duration of Magmatic Processes; Nauka: St. Petersburg, Russia, 2004.

5. Grokhovskaya, T.L.; Lapina, M.I.; Muravitskaya, G.N.; Bakaev, G.F.; Sholokhnev, V.V.; Voitekhovich, V.S. The PGE Ore Mineralization in the Monchegorsk Magmatic Layered Complex (Kola Peninsula, Russia); Nauka: St. Petersburg, Russia, 2003; Volume 45.

6. Sharkov, E.V.; Chistyakov, A.V. Geological and petrological aspects of Ni-Cu-PGE mineralization in the early Paleoproterozoic Monchegorsk layered mafic-ultramafic complex, Kola peninsula. Geol. Ore Depos. 2014, 56, 147-168. [CrossRef]

7. Chashchin, V.V.; Mitrofanov, F.P. The Paleoproterozoic Imandra-Varzuga rifting structure (Kola peninsula): Intrusive magmatism and minerageny. Geodyn. Tectonophys. 2014, 5, 231-256. [CrossRef]

8. Pripachkin, P.V.; Rundkvist, T.V.; Miroshnikova, Y.A.; Chernyavsky, A.V.; Borisenko, E.S. Geological structure and ore mineralization of the South Sopchinsky and Gabbro-10 massifs and the Moroshkovoe Lake target, Monchegorsk area, Kola peninsula, Russia. Miner. Depos. 2016, 51, 973-992. [CrossRef]

9. Grebnev, R.A.; Rundkvist, T.V.; Pripachkin, P.V. Geochemistry of mafic rocks of the PGE-bearing Vurechuaivench Massif (Monchegorsk Complex, Kola region). Geochem. Int. 2014, 52, 726-739. [CrossRef]

10. Rundqvist, T.V.; Pripachkin, P.V.; Bazai, A.V. Plagioclase Composition in Rocks of PGE-Bearing Layered Series in the Vurechuaivench Massif, Monchegorsk Complex, Kola region. Geol. Ore Depos. 2018, 60, 736-743. [CrossRef]

11. Ivanchenko, V.N.; Davydov, P.S.; Dedeev, V.A.; Knauf, V.V. Major features of the Vuruchuaivench (Vurechuaivench) deposit geological structure. In The Neighborhood Cooperation and Experience Exchange for Geological Prospecting and Survey of PGE Deposits in the Northen Fennoscandia. An Interreg-Tacis Project $N$ KA-0197 Vol. 1; KSC RAS: Apatity, Russia, 2008; pp. 82-87.

12. Groshev, N.Y.; Pripachkin, P.V. To the question of the geological position and PGE mineralization of the Gabbro-10 massif, Monchegorsk complex, Kola region. Ores Met. 2018, 4, 4-13.

13. Groshev, N.Y.; Pripachkin, P.V.; Karykowski, B.T.; Malygina, A.V.; Rodionov, N.V.; Belyatsky, B.V. Genesis of a magnetite layer in the Gabbro-10 intrusion, Monchegorsk complex, Kola region: U-Pb SHRIMP-II dating of metadiorites. Geol. Ore Depos. 2018, 60, 486-496. [CrossRef]

14. Karykowski, B.T.; Maier, W.D.; Groshev, N.Y.; Barnes, S.J.; Pripachkin, P.V.; McDonald, I.; Savard, D. Critical controls on the formation of contact-style PGE-Ni-Cu mineralization: Evidence from the paleoproterozoic Monchegorsk complex, Kola region, Russia. Econ. Geol. 2018, 113, 911-935. [CrossRef] 
15. Efimov, A.A.; Subbotin, V.V.; Vursiy, G.L. Geological structure and characterization of sulfide PGE-bearing mineralization of the Gabbro-10 massif (Monchegorsk intrusion, Kola peninsula). In Proceedings of the Materials of the XV Conference of Young Scientists Dedicated to the Memory of K.O. Kratcs, St. Petersburg, Russia, 13-16 October 2004; pp. 726-739.

16. Serov, P.A.; Bayanova, T.B.; Steshenko, E.N.; Kunakkuzin, E.L.; Borisenko, E.S. Metallogenic Setting and evolution of the Pados-Tundra Cr-bearing ultramafic complex, Kola peninsula: Evidence from Sm-Nd and U-Pb Isotopes. Minerals 2020, 10, 186. [CrossRef]

17. Ludwig, K.R. A geochronological toolkit for Microsoft Excel, Version 3.6. Berkeley Geochronol. Cent. Spec. Publ. 2008, 4, 1-76.

18. Williams, I.S. U-Th-Pb Geochronology by Ion Microprobe. In Applications of Microanalytical Techniques to Understanding Mineralizing Processes. Reviews in Economic Geology; McKibben, M.A., Shanks, W., III, Ridley, W.I., Eds.; Society of Economic Geologists: Littleton, CO, USA, 1998; Volume 7, pp. 1-35. ISBN 1-887483-51-9.

19. Schuth, S.; Gornyy, V.I.; Berndt, J.; Shevchenko, S.S.; Sergeev, S.A.; Karpuzov, A.F.; Mansfeldt, T. Early proterozoic $\mathrm{U}-\mathrm{Pb}$ zircon ages from basement gneiss at the Solovetsky archipelago, White Sea, Russia. Int. J. Geosci. 2012, 3, 289-296. [CrossRef]

20. Ludwig, K.R. A geochronological toolkit for Microsoft Excel, Version 2.06. Berkeley Geochronol. Cent. Spec. Publ. 1999, 1a, 1-49.

21. Hölttä, P.; Heilimo, E.; Huhma, H.; Kontinen, A.; Mertanen, S.; Mikkola, P.; Paavola, J.; Peltonen, P.; Semprich, J.; Slabunov, A.; et al. The Archaean Karelia and Belomorian provinces, Fennoscandian shield. In Evolution of Archean Crust and Early Life, Modern Approaches in Solid Earth Sciences 7; Dilek, Y., Furnes, H., Eds.; Springer: Dordrecht, The Netherlands, 2014; pp. 55-102.

22. Middlemost, E.A.K. Naming materials in the magma/igneous rock system. Earth Sci. Rev. 1994, 37, $215-224$. [CrossRef]

23. Condie, K.C. How to make a continent: Thirty-five years of TTG research. In Modern Approaches in Solid Earth Sciences; Springer International Publishing: Dordrecht, The Netherlands, 2014; Volume 7, pp. 179-193.

24. Hölttä, P.; Balagansky, V.; Garde, A.A.; Mertanen, S.; Peltonen, P.; Slabunov, A.; Sorjonen-Ward, P.; Whitehouse, M. Archean of Greenland and Fennoscandia. Episodes 2008, 31, 13-19. [CrossRef]

25. Käpyaho, A.; Mänttäri, I.; Huhma, H. Growth of Archaean crust in the Kuhmo district, eastern Finland: U-Pb and Sm-Nd isotope constraints on plutonic rocks. Precambrian Res. 2006, 146, 95-119. [CrossRef]

26. Mikkola, P.; Huhma, H.; Heilimo, E.; Whitehouse, M. Archean crustal evolution of the Suomussalmi district as part of the Kianta Complex, Karelia: Constraints from geochemistry and isotopes of granitoids. Lithos 2011, 125, 287-307. [CrossRef]

27. Sun, S.-S.; McDonough, W.F. Chemical and isotopic systematics of oceanic basalts: Implications for mantle composition and processes. Geol. Soc. London Spec. Publ. 1989, 42, 313-345. [CrossRef]

28. McDonough, W.F.; Sun, S.-S. The composition of the Earth. Chem. Geol. 1995, 120, 223-253.

29. Rundkvist, T.V.; Pripachkin, P.V.; Grebnev, R.A. On the problem of geological setting and distribution of PGE-mineralization in the Eastern part of the Monchegorsk complex (Kola peninsula)—On the basis of cumulus stratigraphy data. In Strategic Mineral Resources of Lapland-Base for the Sustainable Development of the North. An Interreg-Tacis Project N KA-0197, Vol. 2; Mitrofanov, F.P., Iljna, M., Zhirov, D., Eds.; KSC RAS: Apatity, Russia, 2009; pp. 51-64. ISBN 978-5-91137-094-7.

30. Hölttä, P.; Heilimo, E.; Huhma, H.; Kontinen, A.; Lauri, L.; Slabunov, A. Paleoarchean Rocks in the Fennoscandian Shield. In Earth's Oldest Rocks; Van Kranendonk, M., Bennett, V., Hoffmann, E., Eds.; Elsevier: Amsterdam, The Netherlands, 2019; pp. 819-835.

31. Slabunov, A.I.; Lobach-Zhuchenko, S.B.; Bibikova, E.V.; Sorjonen-Ward, P.; Balagansky, V.V.; Volodichev, O.I.; Shchipansky, A.A.; Svetov, S.A.; Chekulaev, V.P.; Arestova, N.A.; et al. The Archaean nucleus of the Fennoscandian (Baltic) shield. Geol. Soc. Mem. 2006, 32, 627-644. [CrossRef]

32. Hölttä, P.; Heilimo, E.; Huhma, H.; Kontinen, A.; Mertanen, S.; Mikkola, P.; Paavola, J.; Peltonen, P.; Semprich, J.; Slabunov, A.; et al. The archaean of the Karelia province in Finland. In Geological Survey of Finland Special Paper 54; Hölttä, P., Ed.; Geological Survey of Finland: Espoo, Finland, 2012; pp. 21-73.

33. Morozova, L.N.; Bayanova, T.B.; Serov, P.A. The main stages of granite formation in the Archean of the northeast part of the Baltic Shield (on the example of the Voche-Lambina test site). Lithosphere 2011, 6, 14-26. 
34. Corfu, F.; Hanchar, J.; Hoskin, P.W.O.; Kinny, P. Atlas of Zircon Textures. Rev. Mineral. Geochem. 2003, 53, 469-500. [CrossRef]

35. Melezhik, V.A.; Sturt, B.A. General geology and evolutionary history of the early proterozoic Polmak-Pasvik-Pechenga-Imandra/Varzuga-Ust'Ponoy greenstone belt in the northeastern Baltic Shield. Earth Sci. Rev. 1994, 36, 205-241. [CrossRef]

36. Korja, A.; Lahtinen, R.; Nironen, M. The Svecofennian orogen: A collage of microcontinents and island arcs. Geol. Soc. Mem. 2006, 32, 561-578. [CrossRef]

37. Chashchin, V.V.; Bayanova, T.B.; Mitrofanov, F.P.; Serov, P.A. Low-Sulfide PGE ores in paleoproterozoic Monchegorsk pluton and massifs of its southern framing, Kola Peninsula, Russia: Geological characteristic and isotopic geochronological evidence of polychronous ore-magmatic systems. Geol. Ore Depos. 2016, 58, 37-57. [CrossRef]

(C) 2020 by the authors. Licensee MDPI, Basel, Switzerland. This article is an open access article distributed under the terms and conditions of the Creative Commons Attribution (CC BY) license (http://creativecommons.org/licenses/by/4.0/). 